\title{
BRAZIL IN ANTARCTICA: THE SCIENTIFIC AND GEOPOLITICAL IMPORTANCE OF PROANTAR IN THE BRAZILIAN STRATEGIC SURROUNDING AREA
}

Israel de Oliveira Andrade Andrea Cancela da Cruz-Kaled Giovanni Roriz Lyra Hillebrand

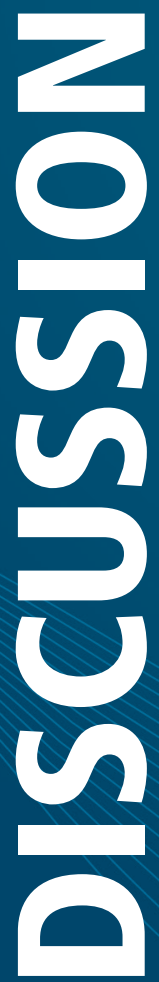





\section{DISCUSSION PAPER}

Brasilia, September 2020

\section{BRAZIL IN ANTARCTICA: THE SCIENTIFIC AND GEOPOLITICAL IMPORTANCE OF PROANTAR IN THE BRAZILIAN STRATEGIC SURROUNDING AREA ${ }^{1,2}$}

Israel de Oliveira Andrade ${ }^{3}$

Leonardo Faria de Mattos ${ }^{4}$

Andrea Cancela da Cruz-Kaled ${ }^{5}$

Giovanni Roriz Lyra Hillebrand ${ }^{6}$

1. This text corresponds to the translation of the research, published originally in Portuguese: O Brasil na Antártica: a importância científica e geopolítica do PROANTAR no entorno estratégico brasileiro. Texto para Discussão n. 2425, Brasilia, Ipea, 2018. 2. We would like to express our sincere gratitude to Admirals Eduardo Bacellar Leal Ferreira and Marcos Silva Rodrigues, and Rear Admirals Sérgio Gago Guida and Paulo Roberto da Silva Xavier. We also thank the staff of the Secretariat of the Interministerial Commission for Sea Resources (SECIRM), the PhD professors Alvaro Toubes Prata - State Secretary of Research and Development Policies and Programs of the Ministry of Science, Technology, Innovation, and Communications (MCTIC) -, Ana Flávia Barros-Platiau and Paulo Eduardo Aguiar Saraiva Câmara - coordinators of graduate programs at the University of Brasilia (UnB) -, and Daniela Portella Sampaio (University of Leeds), as well as the researchers Luiz Gustavo de Aversa Franco, Maurício Kenyatta and Matheus Augusto Soares, of the Research Program for National Development (PNPD) at Ipea, exempting them of any errors or omissions. Any remaining imperfections in the text are sole responsibility of the authors.

3. Researcher at Ipea.

4. Professor of geopolitics at Brazilian Naval War College (EGN).

5. Coordinator of the Department of Sea, Antarctica and Mineral Resources at Ministry of Science, Technology, Innovation and Communications (MCTIC).

6. Researcher in the National Development Research Program (PNPD) at Ipea. 


\section{Governo Federal}

Ministério da Economia

Ministro Paulo Guedes

\section{ipea}

Fundação pública vinculada ao Ministério da Economia, o Ipea fornece suporte técnico e institucional às ações governamentais - possibilitando a formulação de inúmeras políticas públicas e programas de desenvolvimento brasileiros - e disponibiliza, para a sociedade, pesquisas e estudos realizados por seus técnicos.

\section{Presidente}

Carlos von Doellinger

Diretor de Desenvolvimento Institucional Manoel Rodrigues Junior

Diretora de Estudos e Políticas do Estado, das Instituições e da Democracia

Flávia de Holanda Schmidt

Diretor de Estudos e Políticas

Macroeconômicas

José Ronaldo de Castro Souza Júnior

Diretor de Estudos e Políticas Regionais, Urbanas e Ambientais

Nilo Luiz Saccaro Júnior

Diretor de Estudos e Políticas Setoriais de Inovação e Infraestrutura

André Tortato Rauen

\section{Diretora de Estudos e Políticas Sociais} Lenita Maria Turchi

Diretor de Estudos e Relações Econômicas e Políticas Internacionais Ivan Tiago Machado Oliveira

Assessora-chefe de Imprensa

e Comunicação

Mylena Fiori

Ouvidoria: http://www.ipea.gov.br/ouvidoria

URL: http://www.ipea.gov.br

\section{DISCUSSION PAPER}

\begin{abstract}
A publication to disseminate the findings of research directly or indirectly conducted by the Institute for Applied Economic Research (Ipea). Due to their relevance, they provide information to specialists and encourage contributions.
\end{abstract}

(C) Institute for Applied Economic Research - ipea 2020

Discussion paper / Institute for Applied Economic Research.- Brasília : Rio de Janeiro : Ipea, 1990-

ISSN 1415-4765

1. Brazil. 2. Economic Aspects. 3. Social Aspects. I. Institute for Applied Economic Research.

CDD 330.908

Ipea publications are available for free download in PDF (all) and EPUB (books and periodicals).

Access: http://www.ipea.gov.br/portal/publicacoes

The opinions expressed in this publication are of exclusive responsibility of the authors, not necessarily expressing the official views of the Institute for Applied Economic Research and the Ministry of Economy.

Reproduction of this text and the data contained within is allowed as long as the source is cited. Reproduction for commercial purposes is prohibited. 


\section{CONTENTS}

ABSTRACT

1 INTRODUCTION

2 THE ANTARCTIC TREATY:

PRINCIPLES AND HISTORICAL EVOLUTION _...............................................

3 BRAZILIAN EXPERIENCES IN ANTARCTICA

4 BRAZIL AND THE ANTARCTIC SCIENCE

5 PROANTAR AND ITS BUDGETARY ASPECTS:

BACKGROUND AND INVESTMENT PERSPECTIVES

6 FINAL REMARKS AND RECOMMENDATIONS

REFERENCES 



\section{ABSTRACT}

As the most inhospitable continent on Earth, Antarctica has more than $90 \%$ of its territory covered with ice and contains around $70 \%$ of all potable water in the world. Its proximity to South America is especially relevant to Brazil, which includes it in the country's strategic surrounding area. Furthermore, Antarctica is administered through an international regime based on a system of conventions and documents, which defined research activities as its fundamental purpose. The objective of this paper is to present the aspects of the Brazilian Antarctic Program (PROANTAR, in Portuguese), the main instrument of the national Antarctic policy, and the Brazil's continued presence in the continent. In addition, this work aims to depict the importance of Antarctic activities to Brazil, considering not only strategic concerns, but also their relevance to national scientific research. Finally, it investigates PROANTAR's budgetary elements, pointing out its current perspectives, and examines which directions public policies should take to contribute to the program's continuity and strengthening.

Keywords: Antarctica; Brazilian Antarctic Program; research and development (R\&D); strategic surrounding area; geopolitics; maritime power. 



\section{Discussion}

Paper

Brazil in Antarctica: the scientific and geopolitical importance of PROANTAR in the brazilian strategic surrounding area

\section{INTRODUCTION}

Antarctica ${ }^{1}$ is the most inhospitable continent of the planet. The region presents extremely low temperatures, having recorded the lowest temperature across the globe, $-94.7{ }^{\circ} \mathrm{C}$ (Coldest..., 2013). Due to its location, part of the continent (below the Antarctic polar circle) has a permanent presence of the sun during summer, while in the winter months this star appears in the sky only for a short time, making this season almost a permanent night (Redd, 2012; Boano, [s.d.]).

Such harsh characteristics contribute to an almost mystical vision of the Antarctic continent. However, Antarctica's importance for Brazil's foreign policy has not been much discussed in non-specialized environments and in the national media; thus, this subject is mostly unknown to the Brazilian society. With Antarctica included by the 2012 National Defense Policy in the strategic surrounding area of the country (Brazil, 2012c), the Brazilian performance in this continent, through its presence and scientific research, was reinforced as a strategic component. This initiative deepened the international insertion of Brazil and gave visibility to the great relevance of scientific studies developed within the Antarctic region.

This study aims to present the main aspects of the Brazilian Antarctic Program (PROANTAR), which is the instrument of execution of the National Policy for Antarctic Affairs (POLANTAR). To this end, we emphasize the importance of this continent to Brazil by presenting the country's strategic activities and interests in the region, as well as the contribution of the program to national scientific and technological development.

Besides this introduction, this text is organized into five sections. The second section analyzes the history of Antarctica, its exploration phases and the territorial claims of this continent. It also proposes to retrace the international conversations that

1. Also called Antártida in Portuguese. Both terms are considered correct and have the same origin, being accepted in the educated norm. The Brazilian bodies involved in PROANTAR have preferably used Antarctica except for the Ministry of Foreign Affairs (MRE). Moreover, both spellings appear in official Brazilian decrees (Ferreira, 2009). 
resulted in the Antarctic Treaty, signed in $1959 .{ }^{2}$ Thus, we aim to identify different positions and suggestions of the countries regarding the Antarctic continent.

The third section discusses the Brazilian participation in the decisions about Antarctica and the country's activities in the region. It sets the historical milestones that led Brazil to accede to the Antarctic Treaty (1975) and to establish the Comandante Ferraz Antarctic Station (1984), the country's permanent base in the continent. It also mentions the great fire that destroyed most of the Brazilian base in 2012 and the reconstruction process. At last, it presents a brief perspective of PROANTAR in relation to other countries' Antarctic programs.

The fourth section outlines the key aspects of the Brazilian research developed in PROANTAR and the perspectives for national Antarctic science. Considering that scientific studies are the main goal in the Antarctic continent, it is essential to understand the relevance of the projects carried out in the region and the benefits they may achieve.

The fifth section evaluates the budgetary dimension of Antarctic activities performed by Brazil. Thus, it collects data regarding the sums invested in recent years by the bodies responsible for organizing and operating PROANTAR - including logistical, scientific and environmental fields. With this analysis, we aim to understand which activities have required greater investment and how the program has been conceived from the financial point of view.

Finally, the last section resumes the main arguments presented throughout the text to conclude about the importance of Antarctic activities to Brazil, considering not only strategic concerns, but also their relevance for national scientific studies. It also points out the main perspectives for PROANTAR and the guidelines that public policies can take in order to contribute to the continuity and strengthening of the program.

2. The Antarctic Treaty entered into force in 1961, after the deposit of the ratification instrument by the twelve signatory countries. 


\section{Discussion}

Paper

Brazil in Antarctica: the scientific and geopolitical importance of PROANTAR in the brazilian strategic surrounding area

\section{THE ANTARCTIC TREATY: PRINCIPLES AND HISTORICAL EVOLUTION}

The Antarctic continent hosts both the geographic and magnetic South Pole of the Earth. ${ }^{3}$ More than $90 \%$ of its territory is covered in ice, with the main exception being the Antarctic Peninsula, a northern part of the continent where most of research bases are located. With an average temperature between $-30^{\circ} \mathrm{C}$ in summer and $-60^{\circ} \mathrm{C}$ in winter, Antarctica is also the driest continent - based on average rainfall - and the highest - on average altitude on Earth (CIA, 2016). The ice stored in the Antarctic continent totals 25 million cubic kilometers, which is equal to $70 \%$ of the potable water in the world. Added to the existence of more than 170 types of minerals and large natural gas deposits, the scientific and geopolitical relevance of this region increases (Brazil, 2006; SECIRM, 2018).

The dimensions of the Antarctic continent equals to around 1.6 times the extension of Brazil, covering more than 13 million square kilometers. The fauna and flora in the Antarctic sea and land territories are diversified, especially if we consider the harsh climatic conditions in the region (Mattos, 2014; CIA, 2016). The international community's concern for the local ecosystem has culminated in several preservation efforts, such as the Commission for the Conservation of Antarctic Marine Living Resources (CCAMLR), established in 1982, which Brazil joined in 1985. This organization is part of the Antarctic Treaty System, which will be further discussed.

The beginning of the twentieth century brought the first deadlocks regarding sovereignty in the Antarctic territory and its jurisdiction. In 1908, the United Kingdom made the first territorial claim in the continent, followed by New Zealand (1923), France (1924), Australia (1933), Norway (1939), Chile (1940), and Argentina (1940). The main imbroglio happened between the United Kingdom, Argentina, and Chile, who claimed partially coincident areas - such as the Antarctic Peninsula. Not even the signature of a joint declaration in 1949, in which countries committed not to send warships to the continent, could prevent some incidents among these countries in the early 1950s - something that stimulated discussions about the jurisdiction that should prevail in the region (Mattos, 2014).

3. The geographic North and South Poles are defined by the Earth's axis of rotation around itself, whereas the magnetic poles are determined by the axis of symmetry of the planet's magnetic field. The location of the geographic poles is fixed, while that of magnetic poles can change over time. 
FIGURE 1

Overview of territorial claims in Antarctica

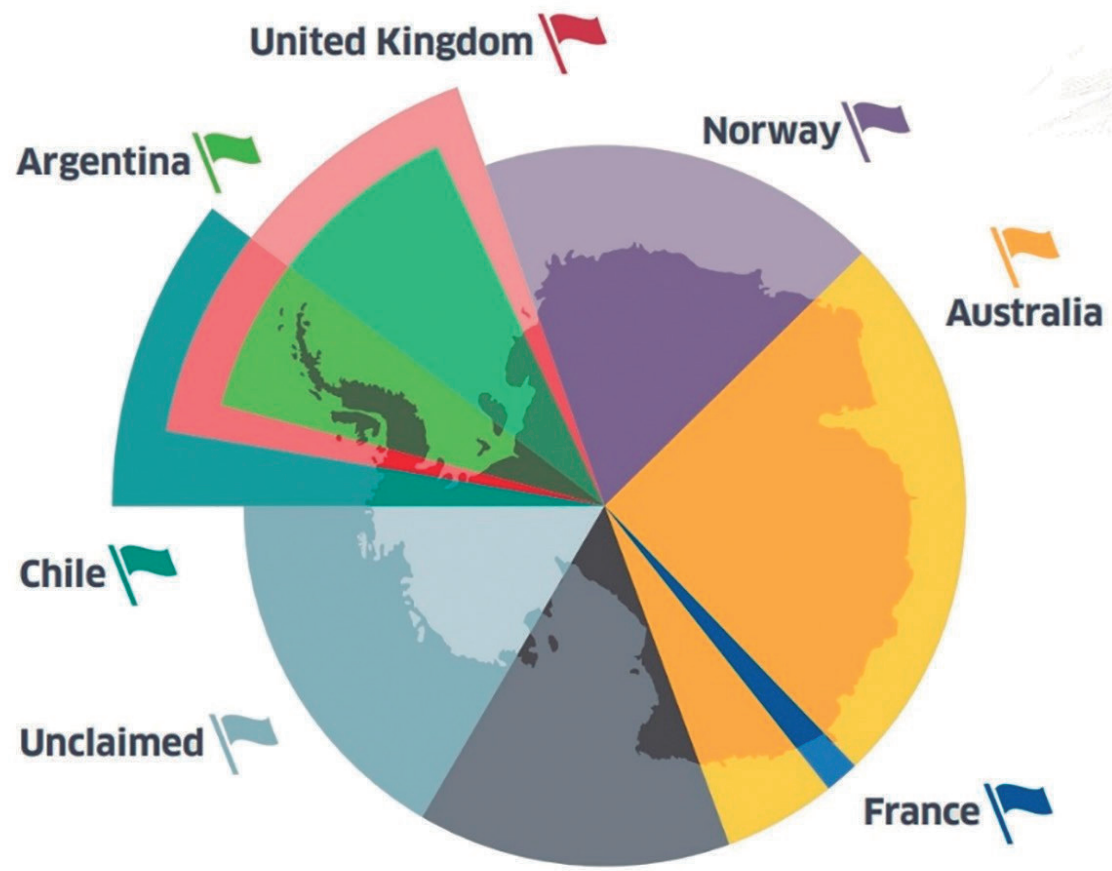

New Zealand

Source: Territorial...([s.d.]).

Over the nineteenth century, marine mammal hunting took many whaling ships to the surroundings of the Antarctic continent. The first one that effectively arrived in Antarctica, in 1820, was the Russian Fabian von Bellinghausen, commander of his country's first expedition to the region (Day, 2013, p. 22). ${ }^{4}$ Between 1882 and 1883 , scientists promoted the International Polar Year, with the aim to conduct geophysical, meteorological and magnetic investigations, and other types of research. Expeditions went to the Arctic and to the South Hemisphere, but none effectively reached the Antarctic continent (Mattos, 2015). ${ }^{5}$

4. However, other explorers are also pointed out as the first to arrive in Antarctica, such as the Spanish Gabriel de Castilla and the North-American Nathaniel Palmer.

5. Currently a scientific program sponsored by the International Science Council (ISC), the International Polar Year had four editions: the first was in the nineteenth century, and the others in the periods 1932-1933, 1957-1958, and 2007-2009. The 1957-1958 edition was called the International Geophysical Year (IGY) because it included research in other regions of the planet. Brazil participated in this edition, but it did not send any expedition to Antarctica (Mattos, 2015). 
The end of World War II (1939-1945) triggered deep geopolitical changes in the international system, which became bipolar with the opposition between North-Americans and Soviets. As soon as the conflict ended, these two countries sent expeditions to Antarctica and concentrated on the jurisdictional situation of the continent. In 1956, the Union of Soviet Socialist Republics (USSR) and the United States built their first scientific bases in the region: Mirny and McMurdo stations, respectively - the latter being the largest station to date (Ferreira, 2009; Mattos, 2014). ${ }^{6}$

In an attempt to resolve the impasses related to Antarctic territory, different proposals emerged at the end of the 1940s and throughout the 1950s. In 1948, the United States sent a memorandum to the countries that claimed territorial possessions in Antarctica, suggesting the internationalization of the continent under the aegis of the United Nations (UN) or any other international organization, or even a shared management - particularly by the Western countries. As this idea contradicted the interest of claimant nations, ${ }^{7}$ the proposal was rejected, but it resulted in a Chilean counterproposal, known as Escudero Declaration. This was the first step to the Antarctic Treaty (Mattos, 2014). This document suggested, among other issues, a moratorium on territorial claims, an agreement for exchange of scientific information, and the guarantee that stations and expeditions to the continent could not be used as justification for future claims (PRB, 1986; Jacobsson, 2011).

The third International Polar Year, between 1957 and 1958, became the International Geophysical Year (IGY), which included several scientific studies, not only in Antarctica. This event represented an important moment in the Cold War history, since it resulted in the cooperation between Western and Eastern countries, including the United States and the USSR. Organized by the International Council of Scientific Unions (later called International Science Council), the IGY contributed to the discussions that followed in the next years, which culminated in the creation of the Antarctic Treaty and its whole system (Buedeler, 1957; Ferreira, 2009). ${ }^{8}$

6. In 1956, the United States opened their second scientific station in the Antarctic continent - Amundsen-Scott -, located in the geographic South Pole. In 1957, the Soviets built the Vostok station, next to the magnetic South Pole of the Earth.

7. Currently, seven countries uphold territorial claims in Antarctica, as presented in figure 1: Argentina, Australia, Chile, France, Norway, New Zealand, and the United Kingdom.

8. The event had the participation of tens of thousands of scientists from 67 countries spread in different regions of the globe, since the IGY studies were not restricted to the Antarctic continent. Fifty research centers were set up in Antarctica by twelve countries: Argentina, Australia, Belgium, Chile, France, Japan, New Zealand, Norway, South Africa, United Kingdom, United States, and USSR. The North-Americans and the Soviets established seven stations each (Buedeler, 1957; Ferreira, 2009). 
The IGY has brought several repercussions concerning the Antarctic issue. Despite the great concern of Western countries with the Soviet presence in the continent, the USSR stated they would keep their scientific bases in Antarctica even after the end of the event. Thus, in 1957, the United Kingdom suggested the creation of a shared management of the Antarctic continent, as the United States had proposed at the end of the previous decade, this time including the USSR. ${ }^{9}$ The British proposal recalled some points of the Escudero Declaration and suggested the creation of a multinational authority. After the inclusion of the demilitarization principle in the continent, the proposal was accepted by the United States and was discussed by countries in the international scenario (Ferreira, 2009; Jacobsson, 2011).

In the beginning of 1958, the IGY was seen as an important opportunity of advances in negotiations for an international treaty about Antarctica; however, the approaching of its closure brought some urgency to this issue. There was a general fear that the USSR would set up military bases in the Antarctic territory at the end of the event which never happened (Jacobsson, 2011).

In May of that same year, the US President Dwight Eisenhower proposed a conference with the countries that set up Antarctic bases during the IGY to create an international regime on the continent. Besides the central points of the Escudero Declaration, this proposal indicated the North-American position about the issue: they would not recognize any existing claim and reserved their right concerning any future territorial claim. The preparatory meetings for the conference presented the principles that would rule the Antarctic Treaty later: freedom of scientific research, use of the region for peaceful purposes only, and the non-requirement of renunciation or recognition of any territorial claim (Ferreira, 2009; Jacobsson, 2011).

The Washington Conference, held from October to December 1959, had few conflicting elements between the participant countries, considering that the terms had been discussed and negotiated in previous meetings. Most countries were willing to make concessions to avoid the Soviets' military presence. Argentina and Chile threatened to

9. According to reports by the British scholar Brian Birley Roberts, who acted in Antarctic issues for the United Kingdom government between the 1940s and the 1970s, the Soviet participation in the discussions still had some resistance from the British, who conducted private meetings with New Zealand and Australia about the subject. Therefore, the Soviet engagement in the Antarctic subject was slow and gradual (Heavens, 2016). 
abandon the conference in case any suggestion of internationalizing the continent was considered, while the USSR insisted in not including any reference to the territorial claims (Ferreira, 2009; Mattos, 2014). The Antarctic Treaty was signed in December 1959 and only entered into force in June 1961, after the ratification by the twelve signatory countries. From that moment on, an international regime was constituted, managed by a system of conventions and documents (Antartic Treaty, 1959). ${ }^{10}$

The Antarctic Treaty comprises fourteen articles, which essentially provide for the coexistence of countries in the continent, promotion of scientific research, performance of inspections, peaceful use of the continent, and institutional issues related to the treaty and its decision-making process. In order to guarantee that countries with territorial claims acceded to the treaty - which were central in the matter -, the claims were mentioned in the document and maintained, but not recognized. Moreover, nothing in the treaty can be considered a renouncement, an enlargement or a reduction of these claims, nor an argument for future requirements (Antartic Treaty, 1959; Mattos, 2014).

Different articles of the treaty establish the use of the continent exclusively for peaceful purposes, prohibiting any military activity - the document does not detail which are those purposes, but it highlights the importance of non-militarizing the continent and reinforces its character of a nuclear-weapon-free zone. ${ }^{11}$ However, the treaty does not prohibits the use of military personnel and equipment to support scientific research or any other peaceful activity, that is why the presence of military officers is common in several bases that operate in Antarctica, in order to provide logistical conditions to research.

It is important to stress that although many scientific stations are held by national Armed Forces (like the Brazilian case), their programs are civilian. Moreover,

10. According to the classical definition by Stephen Krasner, international regimes are "a set of implicit or explicit principles, norms, rules and decision-making procedures around which actors' expectations converge in a given area of international relations" (1983, p. 2).

11. Antarctica was the first region in the globe to be determined as a nuclear-weapon-free zone (NWFZ), which occurred by means of the Antarctic Treaty. Currently, the following international treaties also prohibit nuclear weapons, consequently creating NWFZs: Treaty of Tlatelolco - Latin American and Caribbean (1967); Outer Space Treaty (1967); Seabed Treaty (1972); Treaty of Rarotonga - South Pacific (1985); Treaty of Bangkok - Southeast Asia (1995); Treaty of Pelindaba - Africa (1996); and Treaty of Semipalatinsk - Central Asia (2006). 
scientific research is the main activity conducted in the Antarctic continent. Other important provisions of the document mention the exchange of information and researchers, the publicity of data, and the cooperation with other organizations and international bodies. Responsible for the coordination of scientific programs developed in Antarctica, the Scientific Committee on Antarctic Research (SCAR) was created in 1958 (Antartic Treaty, 1959; Mattos, 2014).

Currently, 53 countries are part of the Antarctic Treaty. Its main decision-making forum, the Antarctic Treaty Consultative Meetings (ATCM), occurs annually and has the participation of member countries, technical-scientific observers (such as SCAR), and experts on the subject. In addition to the twelve original signatories, there is a second category comprising States that have showed substantial scientific research in the region and gained the right to full participate in the ATCMs with vote and veto. Besides the countries in these two categories, called consultative parties, some members, although they ratified the treaty, only participate in the discussions, not taking part in the decision-making process; these are called non-consultative parties (STA, 2017).

In article XII, the Antarctic Treaty provides for the possibility of reviewing its operation within thirty years after entering into force, reached in 1991; however, no country has ever requested any review.

Based on fundamental principles, the Antarctic Treaty changed into a complex set of rules and instruments with the aim to approach different themes related to the continent, originating what we call today Antarctic Treaty System (ATS). Besides the treaty itself, this system comprises the ATCMs, the Special Consultative Meetings, the Meetings of Experts, the Convention for the Conservation of Antarctic Seals (CCAS) (1972), the Convention for the Conservation of Antarctic Marine Living Resources (CCAMLR) (1980), and the Protocol on Environmental Protection to the Antarctic Treaty, also known as the Madrid Protocol (1991).

In addition, some bodies that affect the decision-making process in the continent are also part of the ATS. SCAR, the Committee for Environmental Protection, and the Council of Managers of National Antarctic Programs (Comnap) are some of these bodies. 


\section{Discussion}

\section{Paper}

251 Brazil in Antarctica: the scientific and geopolitical importance of PROANTAR in the brazilian strategic surrounding area

Among the instruments included in the ATS, we can highlight the Madrid Protocol, created in 1991, which banned mining for fifty years in Antarctica, therefore consolidating the environmental character of the treaty, also present in previous conventions. The protocol, which entered into force in 1998, declares the Antarctic continent as a nature reserve and applies to governmental and non-governmental activities. Besides, it prohibits any activities related to mineral resources, except for scientific research purposes. After fifty years of the entry into force of the protocol (therefore in 2048), any consultative party can request a review (STA, 1991). ${ }^{12}$

Tables 1 and 2 show the distribution of countries that participates in the Antarctic Treaty according to their category and signature of the main instruments of the ATS.

TABLE 1

Consultative parties of the Antarctic Treaty

\begin{tabular}{|c|c|c|c|c|}
\hline Country & Entry into force & Madrid Protocol & CCAS1 & CCAMLR $^{2}$ \\
\hline Argentina ${ }^{3}$ & June 23, 1961 & $\checkmark$ & $\checkmark$ & $\checkmark$ \\
\hline Australia ${ }^{3}$ & June 23,1961 & $\checkmark$ & $\checkmark$ & $\checkmark$ \\
\hline Belgium $^{3}$ & June 23, 1961 & $\checkmark$ & $\checkmark$ & $\checkmark$ \\
\hline Brazil & May 16,1975 & $\checkmark$ & $\checkmark$ & $\checkmark$ \\
\hline Bulgaria & September 11, 1978 & $\checkmark$ & & $\checkmark$ \\
\hline Chile³ & June 23, 1961 & $\checkmark$ & $\checkmark$ & $\checkmark$ \\
\hline China & June 08,1983 & $\checkmark$ & & $\checkmark$ \\
\hline Czech Republic & January 10, 1993 & $\checkmark$ & & \\
\hline Ecuador & September 15, 1987 & $\checkmark$ & & \\
\hline Finland & May 15, 1984 & $\checkmark$ & & $\checkmark$ \\
\hline France $^{3}$ & June 23, 1961 & $\checkmark$ & $\checkmark$ & $\checkmark$ \\
\hline Germany & February 05, 1979 & $\checkmark$ & $\checkmark$ & $\checkmark$ \\
\hline India & August 19, 1983 & $\checkmark$ & & $\checkmark$ \\
\hline Italy & March 18, 1981 & $\checkmark$ & $\checkmark$ & $\checkmark$ \\
\hline$J^{\prime a p a n}{ }^{3}$ & June 23, 1961 & $\checkmark$ & $\checkmark$ & $\checkmark$ \\
\hline Netherlands & March 30, 1967 & $\checkmark$ & & $\checkmark$ \\
\hline New Zealand ${ }^{3}$ & June 23, 1961 & $\checkmark$ & & $\checkmark$ \\
\hline Norway ${ }^{3}$ & June 23, 1961 & $\checkmark$ & $\checkmark$ & $\checkmark$ \\
\hline Peru & April 10, 1981 & $\checkmark$ & & $\checkmark$ \\
\hline Poland & June 23, 1961 & $\checkmark$ & $\checkmark$ & $\checkmark$ \\
\hline Russia $^{3}$ & June 23, 1961 & $\checkmark$ & $\checkmark$ & $\checkmark$ \\
\hline South Africa ${ }^{3}$ & June 23, 1961 & $\checkmark$ & $\checkmark$ & $\checkmark$ \\
\hline
\end{tabular}

12. Brazilian Inter-ministerial Commision for Sea Resources (CIRM), Brazil's Superior War College (ESG), and the University of Brasilia (UnB) held, in August 2018, the seminar "Antarctica 2048", which gathered researchers and representatives of the public sector, including military and civil officers. This event addressed the history of PROANTAR, its current situation, and future scenarios. 
Brasilia, September 2020

(Continued)

\begin{tabular}{|c|c|c|c|c|}
\hline Country & Entry into force & Madrid Protocol & CCAS $^{1}$ & CCAMLR $^{2}$ \\
\hline South Korea & November 28, 1986 & $\checkmark$ & & $\checkmark$ \\
\hline Spain & March 31, 1982 & $\checkmark$ & & $\checkmark$ \\
\hline Sweden & April 24, 1984 & $\checkmark$ & & $\checkmark$ \\
\hline Ukraine & October 28, 1992 & $\checkmark$ & & $\checkmark$ \\
\hline United Kingdom ${ }^{3}$ & June 23, 1961 & $\checkmark$ & $\checkmark$ & $\checkmark$ \\
\hline United States ${ }^{3}$ & June 23, 1961 & $\checkmark$ & $\checkmark$ & $\checkmark$ \\
\hline Uruguay & January 11, 1980 & $\checkmark$ & & $\checkmark$ \\
\hline
\end{tabular}

Source: Parties... ([s.d.]).

Authors' elaboration.

Notes: ${ }^{1}$ Convention for the Conservation of Antarctic Seals.

${ }^{2}$ Convention for the Conservation of Antarctic Marine Living Resources.

${ }^{3}$ Originally signatory countries of the Antarctic Treaty.

TABLE 2

Non-consultative parties of the Antarctic Treaty

\begin{tabular}{|c|c|c|c|c|}
\hline Country & Entry into force & Madrid Protocol & CCAS' & CCAMLR ${ }^{2}$ \\
\hline Austria & August 25, 1987 & & & \\
\hline Belarus & December 27, 2006 & $\checkmark$ & & \\
\hline Canada & May 04, 1988 & $\checkmark$ & $\checkmark$ & $\checkmark$ \\
\hline Colombia & January 31, 1989 & & & \\
\hline Cuba & August 16, 1984 & & & \\
\hline Denmark & May 20, 1965 & & & \\
\hline Estonia & May 17, 2001 & & & \\
\hline Greece & January 08, 1987 & $\checkmark$ & & $\checkmark$ \\
\hline Guatemala & July 31, 1991 & & & \\
\hline Hungary & January 27, 1984 & & & \\
\hline Iceland & October 13, 2015 & & & \\
\hline Kazakhstan & January 27, 2015 & & & \\
\hline Malaysia & October 31, 2011 & $\checkmark$ & & \\
\hline Monaco & May 31, 2008 & $\checkmark$ & & \\
\hline Mongolia & March 23, 2015 & & & \\
\hline North Korea & January 21, 1987 & & & \\
\hline Pakistan & March 01, 2012 & $\checkmark$ & & $\checkmark$ \\
\hline Papua New Guinea & March 16, 1981 & & & \\
\hline Portugal & January 29, 2010 & $\checkmark$ & & \\
\hline Romania & September 15, 1971 & $\checkmark$ & & \\
\hline Slovak Republic & January 01, 1993 & & & \\
\hline Switzerland & November 15, 1990 & $\checkmark$ & & \\
\hline Turkey & January 24, 1996 & $\checkmark$ & & \\
\hline Venezuela & March 24, 1999 & $\checkmark$ & & \\
\hline
\end{tabular}

Source: Parties... ([s.d.]).

Authors' elaboration.

Notes: ${ }^{1}$ Convention for the Conservation of Antarctic Seals.

${ }^{2}$ Convention for the Conservation of Antarctic Marine Living Resources. 


\section{Discussion}

Paper

Brazil in Antarctica: the scientific and geopolitical importance of PROANTAR in the brazilian strategic surrounding area

In 2003, the Secretariat of the Antarctic Treaty was established, and it started operating in Buenos Aires in the next year. With exclusively administrative duties, the Secretariat acts as a trustee of the norms established in the ATCMs and gathers information regarding the different bodies that participate in the ATS. Having physical facilities, a staff, and diplomatic privileges, this body developed formal characteristics of an international organization, including its own legal personality (Parties..., [s.d.]).

\section{BRAZILIAN EXPERIENCES IN ANTARCTICA}

Brazil's interest in Antarctica was quite incipient in the end of the nineteenth century and in the first half of the twentieth century, both scientifically and politically. Occasional episodes marked the participation of Brazil in the first Antarctic exploratory efforts: the subantarctic expedition to Punta Arenas, a port city in southern Chile, held in 1882 by Corveta Imperial Parnahyba; and the support to explorers with stopover in the Brazilian territory, particularly in Rio de Janeiro (Ferreira, 2009).

As Brazil had not made any expedition to Antarctica until that moment, it did not actively participate in the political discussions throughout the 1950s about Antarctic issues. Similarly, Brazil was not invited to the Washington Conference in 1959, which resulted in the Antarctic Treaty. As a result, the country sent a diplomatic protest note to the United States. In this document, Brazil reserved its rights of free access to Antarctica and of making any necessary claims. However, it should be noted that the twelve countries that participated in the conference already had made expeditions to the region and developed scientific activities there (Gaubet, 1986; Mattos, 2014).

The first Brazilian to be in Antarctic land was the physician and journalist Durval Rosa Borges, who was invited to visit the continent by the US government. During the trip, which occurred between February and March 1958, Borges sent different news reports to national journals. He published a book detailing his experience in 1959: "Um brasileiro na Antártida" (A Brazilian in Antarctica). Furthermore, still within the scope of IGY (1957-1958), the Brazilian Navy conducted several scientific studies, but only in Brazilian territorial waters. At the time, Brazil did not have proper ships to operate in Antarctica, nor did it have any training for this type of navigation (Mattos, 2015). 
In the second half of the 1950s, important discussions were held internally about how Brazil should perform regarding the Antarctic continent. The strategic importance of Antarctica was highlighted in academic and military circles. For example, a 1957 study by the ESG advised on the non-recognition of other countries' rights to possession, the claim of a territorial portion, and the refuse of any form of internationalization of that region (Mattos, 2015).

A possible territorial claim in Antarctic lands was based on the "defrontation theory", elaborated by professors linked to the Brazilian Institute of Geography and Statistics (IBGE), especially Therezinha de Castro and Carlos Delgado de Carvalho. According to this theory, Antarctica should be divided by the extreme meridians of countries in the South Hemisphere; therefore, Brazil would have right to part of the Antarctic territory. Besides, scholars also mentioned the strong influence of Antarctica in the Brazilian climate as a reason for the claim. Even after Brazil acceded to the Antarctic Treaty in 1975, the speech of more radical territorialists did not end; they kept claiming part of the Antarctic continent throughout the 1970s (Ferreira, 2009).

One of the greatest Brazilian experts on Antarctic issues, the diplomat João Frank da Costa was responsible for preparing an in-depth study on the subject in Itamaraty. By indicating that the agreement signed in Washington was a fact, the diplomat defended that the Brazilian policy regarding Antarctica should start with acceding to the treaty, with the aim to ascend to the position of a consultative party, so that it could fully participate in the decisions about the continent (Costa, 1971).

The Itamaraty sent an Explanatory Statement ${ }^{13}$ to the Presidency of the Republic in 1975 pointing out the Brazilian short and medium-term interests in the Antarctic continent, due to strategic and national security issues, and long-term interest, due to the possibility that Brazil take part in the future commercial use of resources in the region. Moreover, the document refers to the relevance of scientific research as a determining factor to accede to the treaty and mentions the "defrontation theory", showing the influence of territorialists at the time.

13. Explanatory Statement DAM-//124/210 (B29) to the Presidency of the Republic, as of May $2^{\text {nd }}$, 1975. 


\section{Discussion}

Paper

Brazil in Antarctica: the scientific and geopolitical importance of PROANTAR in the brazilian strategic surrounding area

On May $16^{\text {th }}$, 1975, Brazil communicated the United States, trustee of the Antarctic Treaty, about its decision do accede to the treaty. After internal procedures, which were fast, the Decree No. 75.963 , as of July $11^{\text {th }}, 1975$, determined the ratification of the treaty.

Invited by the British government, the Brazilian Navy sent an observer to Antarctica in 1976, the then Lieutenant Commander Luiz Antônio de Carvalho Ferraz, whose name was later chosen to name the first Brazilian station in the region, as a homage. The UK's invitations continued until the end of the 1970s and resulted in the participation of several Brazilian officers as observers of the British program (Ferreira, 2009).

Decrees No. 86.829 and 86.830 , published on January $12^{\text {th }}, 1982$, created the National Commission for Antarctic Affairs (Conantar) and assigned PROANTAR to the Inter-ministerial Commission for Sea Resources (CIRM), coordinated by the Commander of the Brazilian Navy, as the Maritime Authority of the country.

Therefore, PROANTAR is an inter-institutional program executed by the following bodies: the Ministry of Defense (MD), through the Brazilian Navy, responsible for operational and logistic tasks, and the Brazilian Air Force (FAB), which performs flights in support of the program; the Ministry of Foreign Affairs (MRE), responsible for political aspects; the Ministry of Science, Technology, Innovations and Communications (MCTIC), ${ }^{14}$ which defines the program's scientific policy; the National Council for Scientific and Technological Development (CNPq), responsible for funding and coordinating scientific research; the Ministry of Mines and Energy (MME), which, through Petrobras, provides fuel to the program; and the Ministry of the Environment (MMA), engaged in environmental issues. Besides, universities and national research institutes are currently involved in Antarctic studies and activities. ${ }^{15}$

14. Despite the different names of the body throughout the implementation and update stages of PROANTAR, this study will use the current name, MCTIC, in force since 2016. This option aimed to standardize the name through the text.

15. For further information, access the websites of the Brazilian Navy (<https://goo.gl/uoTRsB >), Ministry of Foreign Affairs (<https://goo.gl/qVQeWz>), and Ministry of the Environment (<https://goo.gl/od2ftx>). 
FIGURE 2

Organization chart of PROANTAR

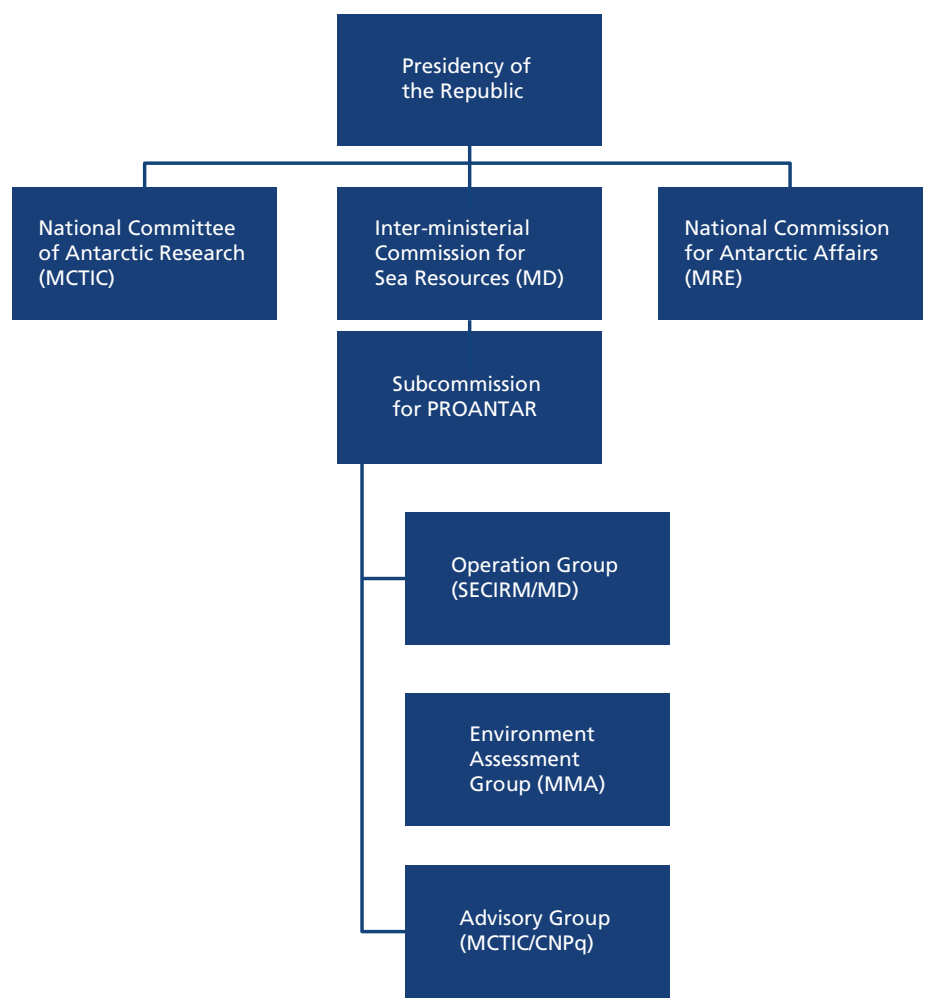

Source: SECIRM. Available at: <https://goo.gl/giSFRG>. Authors' elaboration.

Figure 2 shows that four ministries are directly present in the management of PROANTAR: MD, MCTIC, MRE, and MMA, in addition to research and education institutions, such as universities. CIRM is a collective body coordinated by the Brazilian Navy. It elaborates and executes the National Antarctic Program and works to meet principles and goals defined in POLANTAR, an instrument under the responsibility of CONANTAR (Ferreira, 2009).

The National Committee of Antarctic Research (Conapa) is coordinated by MCTIC, and its main purpose is to advise authorities and bodies regarding scientific subjects of the program and to conduct an institutional relationship with SCAR. ${ }^{16}$

16. For further information, see Decree n. 1791, as of January 15th, 1996. 


\section{Discussion}

Paper

Brazil in Antarctica: the scientific and geopolitical importance of PROANTAR in the brazilian strategic surrounding area

Although different Brazilian scholars had already visited Antarctica on board of foreign ships, the first official Brazilian expedition to Antarctic continent happened between December 1982 and February 1983. It was called Operation Antarctica I, and comprised two vessels. ${ }^{17}$ The operation searched appropriate regions for setting up a station (Ferreira, 2009).

POLANTAR was initially mentioned by the same decree that created CONANTAR. It is currently ruled by Decree No. 123, as of May 20th, 1991. In the beginning of the 1980s, particularly after the first Brazilian trip to Antarctica, the national policy was slowly moving away from territorial interests, consolidating the scientific motivation and political will to participate in the decision-making process of Antarctic issues which happened in 1983 with the approval of Brazil as a consultative party in the ATCM. The possibility of a revision of the treaty in 1991, however, was always present in the Brazilian policy formulation (Ferreira, 2009).

The Comandante Ferraz Antarctic Station (EACF), Brazilian base in Antarctica, was implemented within Operation Antarctica II, in February 1984. The location chosen was Keller Peninsula, on King George Island. Initially built with eight modules, it was enlarged to 33 modules one year later. Only in 1986 the station was permanently occupied by Brazilian researchers and military officers. ${ }^{18}$

Today Brazil is fully integrated into the ATS. Besides being a consultative party of the treaty, the country acceded to SCAR (1984), CCAMLR (1986), and CCAS (1991). Environmental protection in Antarctica has been a fundamental principle of POLANTAR since the 1980s. The negotiations during the Madrid Protocol corroborated the environmental character of the Brazilian presence in Antarctica, when the country was favorable to maximum environmental protection and maximum period of prohibition of exploitation (Ferreira, 2009).

Although the Madrid Protocol entered into force internationally in January 1998, all activities of the Brazilian Antarctic Program have been ruled by these norms since 1991, when the country signed the document.

17. "Barão de Teffé", a polar ship of the Brazilian Navy purchased from a Danish shipyard, and "Professor Besnard", from the Oceanographic Institute of the University of São Paulo (IOUSP).

18. For further information, access the Brazilian Navy's website. Available at: $<$ https://goo.gl/uoTRsB $>$. 
The Brazilian performance in Antarctica has had a great environmental concern, as demonstrated in the disassembly operation due to a fire in the EACF in 2012, and in the monitoring of rebuilding the station by national environmental bodies - as will be detailed further in this text. Corroborating the international recognition of Brazil due to its efforts to perform the best practices when executing activities in Antarctica, many Brazilians have already chaired important multilateral bodies related to the Antarctic theme, such as Antonio Carlos Rocha Campos, in SCAR, between 1994 and 1998; Edith Fanta, in the Scientific Committee of CCAMLR, between 2004 and 2008; and Tânia Brito, who was the vice-president of the Environmental Protection Committee between 2006 and 2008. Since 2016, the glaciologist Jefferson Simóes, one of the main scientists within PROANTAR, has been the vice-president of SCAR.

The 1990s saw a relative distancing between Antarctic issues and national political priorities. From 1995 to 2005, there was not any meeting within Conantar, but operational and research activities remained constant (Ferreira, 2009).

Due to the proximity between the two continents, climate in South America is strongly affected by changes in Antarctica. Even the current geographic configuration of both regions is related, which resulted in environmental consequences to both of them. Therefore, investigating changes in the Southern Ocean circulation, in the Antarctic ice sheet, and in the climate of that region is significant to Brazil. The connection between Antarctic and South American climates will be approached in the next section, with focus on the lines of research defined for national Antarctic science.

The presence of Brazil in Antarctica must also be considered a strategic geopolitical issue among national interests. The main route to access the Antarctic continent is in the South Atlantic. As the country with the largest Atlantic coast in the globe, Brazil observes this region with special attention, where it has its maritime border and commercial, touristic and communication routes. Issues like the existence of mineral resources, such as in the pre-salt layer, also contributes to the relevance of the South Atlantic and therefore Antarctica to Brazil (Abdenur and Souza Neto, 2014; Brazil, 2012b).

According to the Antarctic Treaty, the consultative party status, as the case of Brazil, is linked to the "promotion of substantial scientific research activity there [in Antarctica], such as the establishment of a scientific station or the dispatch of a scientific expedition" (Antartic Treaty, 1959). Therefore, added to the presence in the continent, 
research quality is extremely relevant in the ATS, turning the Antarctic science into a political instrument and part of the agenda of scientific diplomacy (Simóes, 2018).

Not by chance, the 2013 version of the National Defense Policy (PND) included Antarctica in the concept of national strategic surrounding area, together with South America, the South Atlantic and African bordering countries (Brazil, 2012c). ${ }^{19}$ The National Defense Strategy (END) considers the Brazilian participation in the decisionmaking process regarding Antarctica as a means of international insertion of Brazil (Brazil, 2012a). The strategic importance of Antarctica to Brazil is reaffirmed in the Brazilian Defense White Paper, which highlights the influence of the Southern Ocean on the living resources and minerals available in the Brazilian coast (Brazil, 2012b).

In the dawn of February $25^{\text {th }}, 2012$, a fire damaged around $70 \%$ of EACF facilities, causing the death of two Brazilian Navy officers and hurting another. The so-called emergency Antarctic modules (MAE), assembled in the summer after the accident, were used to continue the national scientific research, which was mostly carried out in joint and cooperation activities with other countries over the following years. ${ }^{20}$

The process of rebuilding the station started with Operation Antarctica XXXI, conducted between 2012 and 2013 with the aim to remove the wreckage of the fire - nearly $900 \mathrm{t}$ - and to assemble the MAEs, which have been used by the Brazilian scientific community and Navy, responsible for logistical activities in Antarctica. ${ }^{21}$ Following the environmental principle of Antarctic activities, Brazil conducted a responsible removal of residues, which was supervised by representatives of the MMA and foreign inspectors (Brazil, [s.d.]).

During the seminar "O Brasil e o Sistema do Tratado da Antártica" (Brazil and the Antarctic Treaty System), hosted by the Antarctic Research Center of the University of Sáo Paulo (USP) in 2016, on the occasion of 25 years of the Madrid Protocol, the then Vice-Admiral Marcos Silva Rodrigues ${ }^{22}$ stated that the cleaning and wreckage removal

19. African bordering countries are considered here as those located in the western coast of Africa and, like Brazil, have maritime borders in the South Atlantic.

20. For further information, access the Brazilian Navy's website. Available at: $<$ https://goo.gl/uoTRsB>.

21. The MAEs were purchased from a Canadian company and cost approximately R\$14 million. There were 45 modules, comprising seventeen laboratories and accommodating up to 66 people (Marinha, [s.d.]; Brasil, 2018).

22. Secretary of CIRM between 2012 and 2015. Promoted to Admiral in 2019, after the original publication of this study, he is currently the Chief of the General Secretariat of the Navy (SGM). 
procedures were the greatest logistical operation ever performed by the Brazilian Navy in Antarctica. The operation stood out for its short response time and was a great example of cooperation and coordination between the Navy, FAB, researchers, the Brazilian diplomacy and environment-related national bodies (Rodrigues, 2016). The partnership with the MMA and the conduct of international inspections (a usual practice among ATS member countries) corroborated the fact that all necessary procedures to ensure the compliance with environmental principles ruling Antarctica were executed. ${ }^{23}$

Shortly after the fire, the Brazilian government estimated the new station would be concluded by 2016, but delays when contracting the company responsible for the work postponed the deadline. In 2013, the architectural project to be executed was chosen in a contest to select the best design for the new facilities. The final design of the station was elaborated through intense dialog between the winning company and Brazilian researchers, so that the project was completely national and met all Brazilian needs in Antarctica. Due to the historical importance of the commander Luiz Antônio de Carvalho Ferraz for PROANTAR, the Brazilian station's name remained as a homage to him: Comandante Ferraz Antarctic Station.

The cooperation with other countries was important to ensure the effectiveness of wreckage removal activities and installation of emergency Antarctic modules, with a highlight to the support provided by Chile and Argentina. In January 2013, the EACF was almost completely disassembled, and $50 \%$ of the wreckage had already been dispatched. Throughout this process, there was not any work-related accident, despite the harsh work conditions and difficulties that Antarctica presents (Rodrigues, 2016).

The construction of the new station effectively started in February 2016. It was carried out by the Chinese company China Electronics Import and Export Corporation (Ceiec) and cost US\$ 99.6 million to Brazil. The area of the new station has 4.5 thousand square meters, compared to the previous 2.6-thousand-square-meter area, as well as seventeen laboratories, a library, an ambulatory, a living area, and accommodations for the research and military team in the base, which can host up to 65 people in the summer and 35 in the winter (Brazil, 2016).

23. In the context of disassembling, cleaning and removing the wreckage, the Final Report of the 36th ATCM (held in 2013 in Brussels, Belgium) praised Brazil for its transparency and availability to cooperate with other partners and for the high environmental standards reached (STA, 2013). 


\section{Discussion}

Paper

FIGURE 3

Digital illustration of the new Comandante Ferraz Antarctic Station

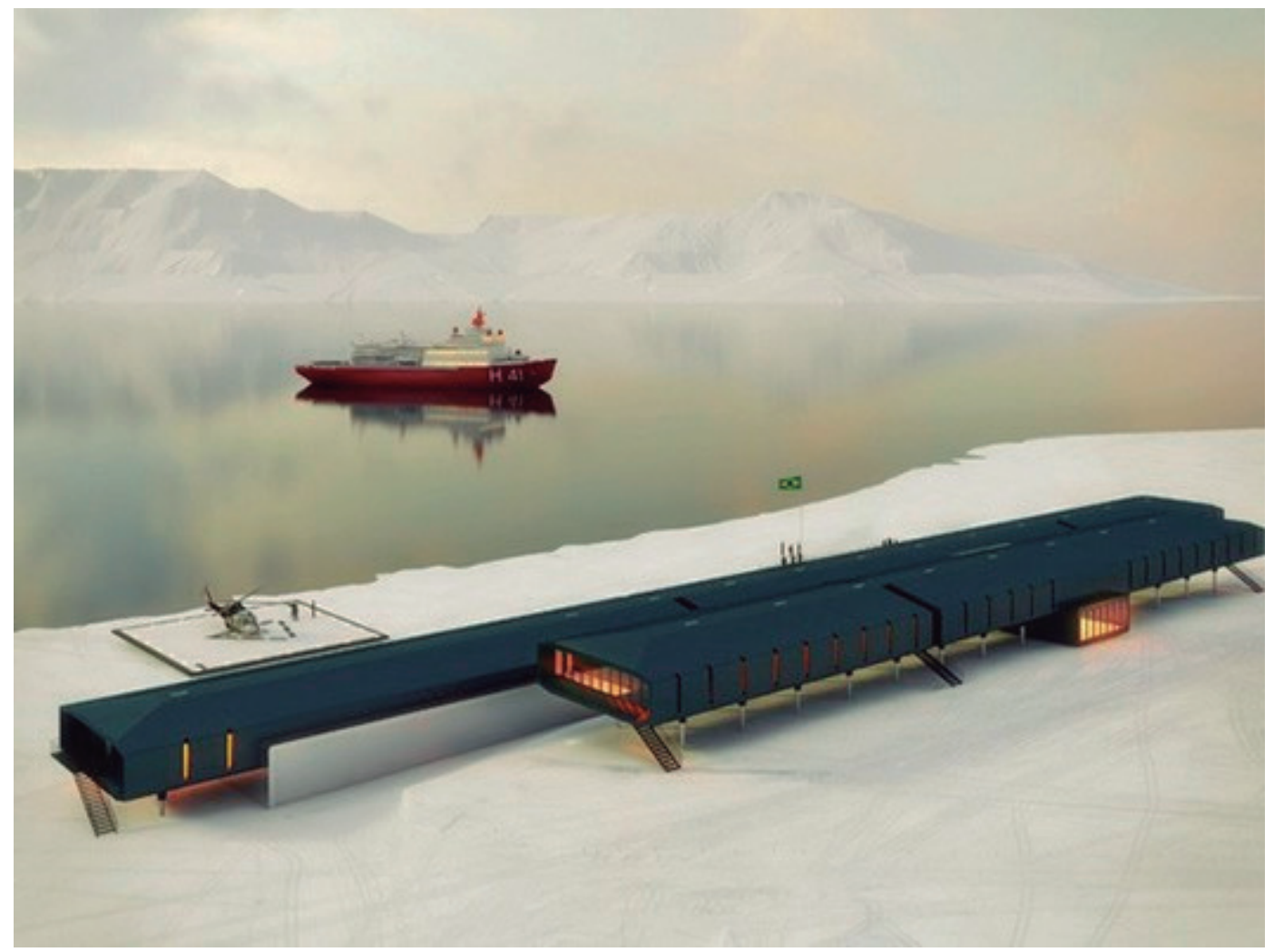

Source: Estúdio 41

In more than three decades, PROANTAR has had an annual average of twenty research projects in several areas - oceanography, biology, glaciology, geology, meteorology, among others -, thus representing an important Brazilian initiative in the scientific field. Since the first national mission to Antarctica in 1982, Brazil performs one operation per year - Operation Antarctica (OPERANTAR). The 36th edition of OPERANTAR happened between 2017 and 2018. ${ }^{24}$

24. Despite the accident in 2012, Brazilian research activities continued; they were carried out in the MAEs, ships, and other countries' stations, reinforcing scientific cooperation in the Antarctic continent. 


\subsection{Brazil in Antarctica: a comparative view}

After exploring several nuances of the Brazilian accession to the Antarctic Treaty and its participation in the ATS, we will present important aspects of the international presence in the Antarctic continent, so that we can understand how the Brazilian performance can be compared to that of other countries.

As aforementioned, Brazil has stood out for its involvement with the ATS, particularly for its strong commitment with environmental issues in the region. In different international forums, PROANTAR was also a reference regarding scientific research programs and environmental protection. In IBSA (a forum comprising India, Brazil and South Africa), the Science and Technology Working Group has Antarctic cooperation in its agenda (Ferreira, 2009). Regarding the BRICS (a group comprising Brazil, Russia, India, China, and South Africa), a new plan for science, technology and innovation (ST\&I), to be released until 2018, ${ }^{25}$ must cover the Antarctic theme as well (Brazil, 2013b; India..., 2016).

Concerning funding, Brazil, as a consultative party, is committed to contribute financially to the Antarctic Treaty through its Secretariat. Ranked in category "D" in the contribution scale, Brazil has the duty to send approximately US\$ 40,000 every year to the body (STA, 2017). Table 3 presents the contributions of each country.

TABLE 3

Annual contribution scale to the Secretariat of the Antarctic Treaty

\begin{tabular}{lcc}
\hline Country & Category & Total contribution (in US\$) \\
\hline Argentina & A & 60,437 \\
Australia & A & 60,437 \\
Belgium & D & 40,021 \\
Brazil & D & 40,021 \\
Bulgaria & E & 33,923 \\
Chile & C & 46,119 \\
China & C & 46,119 \\
Czech Republic & D & 40,021 \\
Ecuador & E & 33,923 \\
Finland & D & 40,021 \\
\hline & &
\end{tabular}

25. After the publication of the original version of this text, the BRICS Science, Technology and Innovation Work Plan 20192022 was released. The document provides for the creation of an Ocean and Polar Science and Technology Working Group, thus comprising Antarctic issues. More information at: <https://bityli.com/2s0kS>. 


\begin{tabular}{lcc}
$\begin{array}{l}\text { Discussion } \\
\text { Paper }\end{array}$ & & \\
\hline 251 & Brazil in Antarctica: the scientific and geopolitical importance of PROANTAR in the brazilian strategic surrounding area \\
\hline & & \\
(Continued) & Category & Total contribution (in US\$) \\
\hline Country & A & 60,437 \\
\hline France & B & 52,216 \\
German & C & 46,119 \\
India & B & 52,216 \\
Italy & A & 60,437 \\
Japan & C & 46,119 \\
Netherlands & A & 60,437 \\
New Zealand & A & 60,437 \\
Norway & E & 33,923 \\
Peru & D & 40,021 \\
Poland & C & 46,119 \\
Russia & C & 46,119 \\
South Africa & D & 40,021 \\
South Korea & C & 46,119 \\
Spain & C & 46,119 \\
Sweden & D & 40,021 \\
Ukraine & A & 60,437 \\
United Kingdom & A & 60,437 \\
United States & D & 40,021 \\
Uruguay & & $1,378,097$ \\
Total & & \\
\hline \multicolumn{1}{c}{ Source: STA (2017). } \\
$\quad$ Authors' elaboration. & & \\
& & \\
\hline & & \\
\hline
\end{tabular}

In addition to the annual contribution to the Secretariat of the Antarctic Treaty, as shown in table 3, Brazil also financially contributes to SCAR in the category "well developed programs" of the body. In 2017, the sum set for Brazil was US\$17,100; for 2018, the sum predicted is US\$21,200, due to regular adjustments (Overview..., [s.d.]). While the contribution to the Secretariat is paid through the MRE, the MCTIC is responsible for paying SCAR. Brazil also contributes to CCAMLR (MRE) and Comnap (MD), which corroborates the country's commitment to the development of the ATS.

Setting up scientific stations and dispatching expeditions to the Antarctic continent can be understood as essential activities, because they are provided in the Antarctic Treaty as ways of showing substantial scientific interest in the region and, therefore, achieving and maintaining the consultative party status in the treaty. Based on a survey conducted within the scope of this research, table 4 displays the number of year-round and seasonal stations of each country in Antarctica until 2017. 


\section{TABLE 4}

\section{Facilities in Antarctica per country}

\begin{tabular}{|c|c|c|c|c|}
\hline Country & Year-round stations & Seasonal stations & Other facilities ${ }^{1}$ & Total \\
\hline Argentina & 6 & 7 & 0 & 13 \\
\hline Australia & 3 & 1 & 2 & 6 \\
\hline Belarus & 0 & 1 & 0 & 1 \\
\hline Belgium & 0 & 1 & 0 & 1 \\
\hline Brazil & 1 & 0 & $1^{2}$ & 2 \\
\hline Bulgaria & 0 & 1 & 0 & 1 \\
\hline Chile & 3 & 7 & 2 & 12 \\
\hline China & 2 & 1 & 1 & 4 \\
\hline Czech Republic & 0 & 1 & 0 & 1 \\
\hline Ecuador & 0 & 1 & 1 & 2 \\
\hline Finland & 0 & 1 & 0 & 1 \\
\hline France & 1 & 0 & 2 & 3 \\
\hline France/Italy & 1 & 0 & 0 & 1 \\
\hline Germany & 2 & 3 & 0 & 5 \\
\hline India & 2 & 0 & 0 & 2 \\
\hline Italy & 0 & 1 & 4 & 5 \\
\hline Japan & 1 & 0 & 1 & 2 \\
\hline Netherlands & 0 & 0 & 1 & 1 \\
\hline New Zealand & 1 & 0 & 0 & 1 \\
\hline Norway & 1 & 0 & 1 & 2 \\
\hline Peru & 0 & 1 & 0 & 1 \\
\hline Poland & 1 & 0 & 0 & 1 \\
\hline Russia & 7 & 5 & 0 & 12 \\
\hline South Africa & 1 & 0 & 0 & 1 \\
\hline South Korea & 2 & 0 & 0 & 2 \\
\hline Spain & 0 & 2 & 1 & 3 \\
\hline Sweden & 0 & 1 & 0 & 1 \\
\hline Ukraine & 1 & 0 & 0 & 1 \\
\hline United Kingdom & 2 & 0 & 2 & 4 \\
\hline United States & 3 & 0 & 4 & 7 \\
\hline Uruguay & 1 & 1 & 0 & 2 \\
\hline
\end{tabular}

Source: Comnap (2017).

Authors' elaboration.

Notes: ${ }^{1}$ It includes small stations, called refuges, airfields, laboratories, camps, and depots.

${ }^{2}$ It refers to the installation of the first Brazilian module in the ice sheet of Antarctica - the "Criosfera 1". Its goal is to observe the atmosphere, a key factor to better understand recent climate changes in the continent. Thus, this module automatically and continuously collects and provides important meteorological and atmospheric data (including CO2 concentration). Besides, the "Criosfera 1" allows Brazil to carry out scientific expeditions to the inner part of Antarctica. 


\section{Discussion}

Paper

Brazil in Antarctica: the scientific and geopolitical importance of PROANTAR in the brazilian strategic surrounding area

Table 4 shows that thirty countries have research bases in Antarctica. ${ }^{26}$ Among these, nineteen have at least one year-round station. The Argentine, Chilean, Russian, and US Antarctic programs stand out with the largest amount of bases set up - which is why they will be particularly approached below. From the countries with year-round stations, ten have more than one station of this type, while the other nine have only one, like Brazil. All consultative parties have at least one research station in Antarctica, which highlights the relevance of such facilities for an effective participation in the Antarctic regime.

With a prominent presence in Antarctica, Argentina participated in the 1959 Washington Conference and, consequently, has been part of the Antarctic Treaty since its creation. It is the closest country to Antarctica (nearly 1,000 kilometers) and has six year-round bases and seven seasonal bases in the continent - the largest number among all countries, as shown in table 4. Besides, the head office of the Secretariat of the Antarctic Treaty is based in Argentina and started its activities in Buenos Aires in September 2004 (Argentina..., 2016; Comnap, 2017).

Despite the large number of stations, for more than two decades Argentina had only one polar ship, the icebreaker ARA "Almirante Irízar", and advertised for bids every year to rent polar vessels to its Antarctic missions (Argentina..., 2016). The country's icebreaker went on fire in 2007 and was back to operation in the 2017-2018 summer. In order to equip the Navy and support missions, the Argentine government purchased four polar ships from Russia in 2015: ARA "Estrecho de San Carlos", ARA "Puerto Argentino", ARA "Islas Malvinas", and ARA "Bahia Agradable" (Argentina..., 2015).

As the EACF does not have an airstrip for FAB's aircrafts, which supports Brazilian activities in Antarctica, there is a close relationship between Brazil and Chile concerning PROANTAR operation, since Brazilians use the airstrip of the Chilean Antarctic base, called Presidente Eduardo Frei Montalva Station.

Today there are 33 stations in the Antarctic continent with at least one airstrip. In the King George Island, where EACF is based, there are only two airstrips - the other is located in the Argentine station Carlini. These two airstrips are considerably

26. Table 4 also includes Concordia Station, jointly operated by France and Italy. 
different: while the one in the Carlini Base is 400 meters long and 40 meters wide, the one in Eduardo Frei Base is 1,300 meters long and 100 meters wide, which allows for the operation of larger planes. The Chilean station also allows for joint operations (air and sea), whereas the Argentine base holds only air operations (Comnap, 2017). ${ }^{27}$

Besides the Frei airstrip, Brazil has used the Chilean city Punta Arenas as a supporting area for ships and FAB's aircrafts, which depart from that city to Antarctica. The airport and the port located in Ushuaia, Argentina, can also be eventually used for this support. The preference for the Chilean city in Brazilian operations is mainly due to the lower cost. Moreover, Ushuaia does not have a tug, thus docking at this port depends on meteorological conditions (Mattos, 2015).

Although the lack of an airstrip is one of the main logistical fragilities of PROANTAR, the partnership between the Brazilian and Chilean Antarctic programs also benefits the latter, for example, by significantly moving the economy in Punta Arenas. Besides, several Antarctic programs, other than PROANTAR, use Chilean and Argentine cities as departures and supporting areas for operations. Therefore, as previously mentioned, the cooperation element is strong in the ATS.

To replace the icebreaker AP-46 "Almirante Viel", built in Canada in the 1960s and purchased by Chile in 1994, the Chilean Navy entered into a contract with the state-owned company Astilleros y Maestranzas de la Armada (Asmar) in 2015 to elaborate the concept definition of a future ship. In February 2017, the government authorized the building of the vessel, which will be the first icebreaker produced in Latin American. The ship is expected to start operating in 2022 and to meet the needs of the country in Antarctica for thirty years (García, 2017a; 2017b; Proyecto..., 2017).

As world powers that polarized international political issues during the Cold War, when the Antarctic Treaty was signed, the United States and Russia are also important players in the Antarctic region. Both were quite relevant in the discussions that culminated in the treaty; being signatories of the document. The US are also the trustees of this document and of the Madrid Protocol (Campos, 2017).

27. The Eduardo Frei Station has the only airfield in Antarctica with an IATA code (provided by the International Air Transport Association), which identifies all airports around the world. 


\section{Discussion}

Paper

Brazil in Antarctica: the scientific and geopolitical importance of PROANTAR in the brazilian strategic surrounding area

Russia is the country with the highest number of year-round stations in the Antarctic continent: seven. The supplying of its bases and the logistical aspects of its Antarctic program are ensured through the use of aircrafts and two supporting cities for flights, Punta Arenas (Chile) and Cape Town (South Africa) (Comnap, 2017).

With an increasing presence in Antarctica, Russians have made efforts in research undertaken in the region and achieved, for example, relevant results in the development of their own global positioning system - the Global Navigation Satellite System (Glonass) $-{ }^{28}$ with the aim to challenge the US GPS system (Romero, 2015). Moreover, Russian opposed an initiative within CCAMLR which proposed the creation of a protected area of more than 1.5 million square kilometers in Eastern Antarctica - a marine sanctuary. As consensus is necessary in the decision-making of this body, the proposal was not approved. The alleged motivation for the Russian opposition was mainly based on fishing interests in the region - as other countries have already done, such as China, Japan, and South Korea (Feast, 2015; Bender, 2016).

The United States have currently three year-round stations in Antarctica. They have the largest base in the continent, the McMurdo station, opened in 1956. It has space for up to 1,258 people and has more than 100 buildings, including a port, three airfields, and a helipad. A project to modernize the station has been approved recently, and the building of new modules must start in 2019, with expected conclusion in 2024 (Comnap, 2017; Fowler, 2017).

Considering this section and the financial contributions to the Secretariat of the Antarctic Treaty, Brazil is in a category below the other countries mentioned Chile, Argentina, United States, and Russia. On the other hand, as tables 1 and 2 in the previous section corroborate, Brazil is in a significant position regarding its commitment with the Antarctic Treaty System. Except for Argentina, Brazil is the only country among those analyzed which signed all major instruments of the system currently in force. ${ }^{29}$

28. Globalnaya Navigatsionnaya Sputnikovaya Sistema.

29. To date, the only instrument Brazil did not ratify related to the ATS is the Annex VI of the Madrid Protocol. This annex was presented in 2005 and concerns countries' liability arising from environmental emergencies in Antarctica. It is not yet in force because not all consultative parties have approved it (Annex..., [s.d..]; Parties..., [s.d.]). 


\section{BRAZIL AND THE ANTARCTIC SCIENCE}

Considering the difficulties imposed by climate and access conditions in Antarctica, we must highlight the indispensable participation of the Brazilian Navy and FAB in the operation of PROANTAR. One of the major purposes of their activities is to ensure the full development of the national scientific research in Antarctica, with focus on Antarctic operations and continuous presence in the EACF. Therefore, it is necessary to understand the way science is inserted in PROANTAR and which are the main benefits achieved by funding this program.

As presented previously, based on the determination of peaceful use of Antarctica, research activities are the fundamental purpose of occupying the continent. In article IX, the Antarctic Treaty provides for that all countries that become members of the treaty by accession, like Brazil, must maintain a substantial scientific program in order to grant their right to participate in meetings that deliberate over the region (Antartic Treaty, 1959). Therefore, the Brazilian investment in the Antarctic science also strengthens its geopolitical interests.

Several Brazilian universities and research institutes develop important projects in Antarctica that positively impact pure and applied sciences and contribute to the formation of human resources, promoting scientific and technological advances in Brazil. Projects executed within PROANTAR have partnerships with several countries, resulting in the internationalization of the Brazilian science. Currently, the national Antarctic research is divided into different lines, and its progress has reflexes even in the daily life of society. Among the potential effects of biotechnological research, for example, we can underline benefits for medicine (drug formulation), agriculture (development of new pesticides and herbicides) and industry (manufacturing of products such as anticoagulants and sunscreens) (Dantas, 2018).

Considering that PROANTAR's major goal is to produce scientific knowledge about Antarctica and its relationships with other world regions, particularly with Brazil, the 2016-2022 "National Strategy for Science, Technology and Innovation" (ENCTI), elaborated by MCTIC, draws special attention to the Antarctic subject. This document particularly advocates the expansion of research in Antarctica and its adjacent area (Brazil, 2016b). 
In order to face challenges related to climate change, sustainable use of natural resources, and food, energy and water security, ENCTI underlines the importance of Antarctica to maintain the world climate and reinforces the existence of direct impacts of that region on the whole globe. It also highlights the connection between the continent and geopolitical issues by mentioning strategic global resources in Antarctica, the Brazilian performance in the South Atlantic, and national water and energy security (Brazil, 2016b).

The document "Antarctic Science for Brazil" is an action plan produced in 2013 by the MCTIC and focused on the 2013-2022 period. It provides for the undertaking of research in Antarctica and in the Southern Ocean in five thematic programs, focusing on the investigation of environmental processes and relationships between South America and the polar region. The action plan and the programs developed aim to increase Brazil's role in the ATS, especially in SCAR, the major scientific body regarding Antarctica (Brazil, 2013b).

The first thematic research program determined by the action plan is called "The role of cryosphere in the Earth's system and its interactions with South America”. It investigates the influence of the Antarctic cryosphere in the South hemisphere climate, with emphasis in the South American continent. ${ }^{30}$ Monitoring variations in the Antarctic ice sheet is essential to elaborate possible future scenarios of climate change in Brazil. The second program defined for PROANTAR, called "Biocomplexity of Antarctic ecosystems, their connections with South America, and climate change", investigates especially the origin and evolution of the Antarctic biodiversity. These studies aim to better understand the effect of environmental changes on biological diversity, resulting in knowledge that can support public policies and political decisions about the theme (Brazil, 2013b).

The third research program of the action plan is called "Climate change and the Southern Ocean". It analyzes processes associated with changes in the Southern Ocean circulation that can affect the climate in South America and, for example, increase the

30. The term cryosphere refers to all elements of the Earth system that have water in the solid state, including marine, river and lake ice; snow cover; solid precipitation; seasonally frozen soils; ice in the subsoil; ice caps; and, mainly, the two ice sheets of Earth: Antarctica and Greenland (A criosfera..., [s.d.]). 
sea level in the globe. The fourth research thematic line of PROANTAR, "Geodynamics and geological history of Antarctica and its relationships with South America”, investigates the mechanisms that resulted in the current Antarctic geographical configuration and the environmental consequences of any changes that occur in the continent. In this context, the existence of oil reservoirs in the region, although protected by the Madrid Protocol, reinforces the economic and geopolitical character of Antarctic research (Brazil, 2013b).

The fifth and last priority thematic program for the Brazilian Antarctic research, "Upper atmosphere dynamics in Antarctica, interactions with geospace and connections with South America", investigates chemistry in the upper atmosphere and ozone reduction in the Antarctic climate. Due to the conditions of sky observation and the location of Antarctica, several astronomy projects have been carried out in the region, which allows for the detection of cosmic rays and the study of dark matter and exoplanets (Brazil, 2013b).

Besides presenting the priority lines of Antarctic research, the action plan highlights research possibilities in social sciences: archeology, science sociology, political geography, and international relations. Studies on vectors of communicable diseases and psychology of groups under extreme conditions are also examples of study areas to be explored, as well as human biology and polar medicine. It is also important to conduct investigations about the connections between Antarctica and the Arctic, which have similar characteristics to be better explored (Brazil, 2013b).

Regarding the development of public policies for the national Antarctic science, the action plan points out the need for a joint action between CNPq and Capes (Coordination for the Improvement of Higher Education Personnel) to issue calls for research grants dedicated to studies on polar subjects. For example, some emerging Antarctic science areas have few or zero researchers in Brazil (Brazil, 2013b).

The plan also suggests the continuity of integration between Antarctic studies and ongoing scientific programs, as well as the promotion of actions within the Ministry of Education (MEC) to stimulate Federal Higher Education Institutions (IFES) to open selection processes for professors working on Antarctica-related subjects (Brazil, 2013b). The maintenance of quality research in the Antarctic continent is grounded in 
the continued formation of expert researchers; therefore, the increase in the number of professors is an important action to strengthen national Antarctic science.

The Science and Technology National Institutes program (INCT), coordinated by the MCTIC and executed by CNPq, aims to boost national scientific research and stimulate the development of high-level science and technology, promoting the advancement of Brazil's competence in many areas of interest. Within PROANTAR today, we can highlight the INCT for Cryospheric Sciences (INCT Cryosphere), located in the Federal University of Rio Grande do Sul (UFRGS). ${ }^{31}$

Science developed within PROANTAR also contributes to other institutes, such as the INCT for Climate Change, the INCT for Tectonic Studies, and INCTs related to sea sciences and oceanography. Other national entities with cooperation links with Brazilian scientific projects executed in Antarctica are the Brazilian Panel on Climate Change (PBMC), the Brazilian Research Network on Global Climate Change (Rede Clima), and the Mineral Resource Research Company (CPRM) ${ }^{32}$ (Brazil, 2013b).

With the aim to support national Antarctic scientific projects, the MCTIC and CNPq released calls in 2009 and 2013 to select research proposals to receive financial support. Call n. 64/2013 approved twenty research projects, granting them $\mathrm{R} \$ 13.8$ million in total. Although the execution term was 36 months, the absence of a new call and budget constraints resulted in an extension of the term for another twelve months, which was carried out by means of an amendment added between 2016 and 2017, as will be further explained in the next section (Brazil, 2013a)..$^{33}$

31. The last call of this program was published in 2014 and selected 135 INCTs. Institutes are organized into eight different fields of knowledge: health (39), ecology and environment (31), agriculture (12), engineering and information technology (12), hard and natural sciences (11), energy (10), soft and social sciences (10), and nanotechnology (10). For further information, access the program's website. Available at: <http://inct.cnpq.br/>.

32. Also called Geological Survey of Brazil. For further information, access the institution's website. Available at: <https:// goo.gl/qG9h1a>.

33. In August 2018, the MCTIC issued the Call No. 21/2018 in partnership with Capes (Ministry of Education), with the aim to support scientific, technological and innovative research projects within PROANTAR. The financial resources destined to projects add up to almost $R \$ 18$ million, deriving from the following sources: $R \$ 1.5$ million from $C N P q ; R \$ 3.7$ million from MCTIC; R\$ 5.7 million from Capes; R\$ 7.1 million from the National Fund for Scientific and Technological Development (FNDCT) (approximate values). As this call is very recent and is in progress, we cannot assess its results or effects. Therefore, further considerations can be presented in future studies. 
It is important to emphasize once again that the logistics to develop the projects approved requires the participation of the Brazilian Navy and the FAB, particularly in order to carry out research in the Southern Ocean on board of ships. They also ensured the transportation of scientific teams to different regions of Antarctica and maintained EACF. In this context, according to data provided by the General Coordination for Oceans, Antarctica and Geosciences (CGOA), of the MCTIC, out of the twenty projects funded by the 2013 call, five provided for activities exclusively developed in the Brazilian station, thirteen demanded the use of ships, one required the use of refuges, ${ }^{34}$ and one proposed its own logistics (MCTIC, 2017).

In order to comply with PROANTAR's scientific agenda, it is necessary to invest resources in the regular and planned issuance of calls that support Antarctic science. This is a pathway to guarantee the continuity of national research in the region and, consequently, of the Brazilian political performance in the ATS. In order to better explore and comprehend the budgetary issue of PROANTAR, the next section will assess the track record of resources sent to this program and investment perspectives.

\section{PROANTAR AND ITS BUDGETARY ASPECTS: BACKGROUND AND INVESTMENT PERSPECTIVES}

Throughout 2017, different national communication media published about the concern of scientific community members about budgetary constraints within ST\&I and scientific research in Brazil. In this context, the Antarctic science and PROANTAR could be hardly impaired by such restrictions. The scientific participation of Brazil in OPERANTAR XXXVI, which began at the end of 2017, happened due to an emergency release of funds by MCTIC. However, it should be noted that investments in the rebuilding of the EACF continued in parallel (Chiaretti, 2017; Descontinuidade..., 2015).

This section aims to explain the different investment sources of PROANTAR and their applications. To better understand the program's budgetary issue, we must analyze separately the sums from different ministries and bodies that contribute to funding.

34. Refuges are small stations located in Antarctica for researchers who need to access regions farther from research stations. 


\section{Discussion}

Paper

Brazil in Antarctica: the scientific and geopolitical importance of PROANTAR in the brazilian strategic surrounding area

In order to analyze the recent overview of PROANTAR and activities developed by Brazil in Antarctica, we gathered budgetary information from the main bodies responsible for executing the program. Thus, we will present historical series regarding MD, which approaches logistical aspects of the Brazilian presence in Antarctica; MCTIC, related to scientific activities carried out in the region; and MMA, responsible for environmental and sustainability aspects.

Despite the segmentation of funding sources, the cost of equipment and logistical activities to carry out scientific research includes, among other elements, the provision of food, drugs, camping material, and Antarctic clothing; maintenance of ships, aircrafts (such as helicopters boarded on ships), supporting vehicles, power generators, and machinery; and pre-Antarctic training. Such tasks, among others, are fundamental in the execution of research projects developed in the region.

Thus, it is difficult to dissociate investments in logistical activities from those directly destined to Antarctic research. Even sums directed to the activities listed above, essentially logistical at first sight, can be considered as resources that subsidize the national scientific activity developed in Antarctica. In this sense, the analyses along this section will be presented according to institutions of origin only for methodological purposes.

In order to develop a thorough analysis on the most recent changes in PROANTAR's budget, we considered a time range of ten years so that we will present sums regarding the period from 2008 to 2017. First, we will analyze the resources used by each body; then, at the end of the section, it will be possible to assess the investments in PROANTAR as a whole..$^{35}$

Several bodies have directly invested in the continuous development of national Antarctic science - besides the MCTIC and CNPq, we can underline occasional contributions by Capes, by the Foundation for Research Support of the State of Rio Grande do Sul (FAPERGS), and by the Joint Parliamentary Front in Support of the Brazilian Antarctic Program. Graph 1 shows the most recent investments of these institutions.

35. We collected information by means of data available in the Financial Administration Integrated System of the Federal Government (SIAFI) and Portal Siga Brasil, of the Federal Senate. Besides, information on resources specifically directed to national Antarctic research was provided by CGOA/MCTIC. 


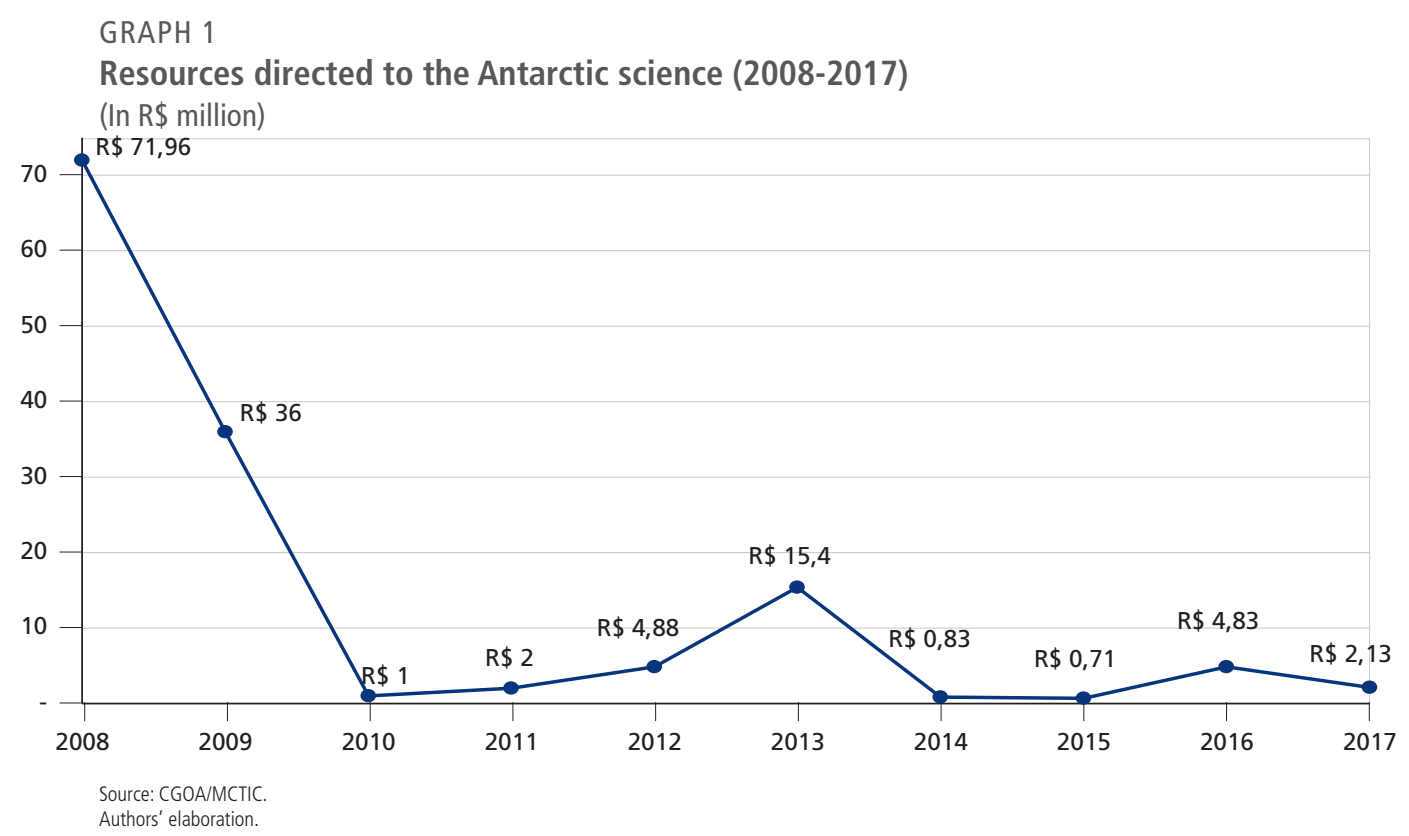

According to graph 1, the amount of resources in 2008 and 2009 is much higher than in other years. This is due to the purchase of the polar ship Almirante Maximiano in 2008 ( $\mathrm{R} \$ 71$ million) and equipment to this ship in the next year ( $\mathrm{R}$ 10 million). Such investments were made after an agreement between Finep (Studies and Projects Financing Agency), Fundep (Research Development Foundation), and the Brazilian Navy. Still in 2009, considerable sums were destined to Antarctic INCTs (R\$ 12 million from the MCTIC) and to CNPq and MCTI's Call No. 23/2009, which selected and funded Antarctica-related research projects ( $\mathrm{R} \$ 14$ million from amendments issued within the Parliamentary Front).

Other important information is the replacement of scientific equipment lost in the fire at the EACF in 2012. It demanded around R \$ 4.2 million, which came mostly from the MCTIC and corresponded to the largest part of resources invested in the Antarctic science that year.

The figures for 2013 also stand out in graph 1 . The sum of this year was destined to MCTI/CNPq/FNDCT's Call No. 64/2013, which provided approximately R $\$ 13.8$ million to the twenty projects selected - around $\mathrm{R} \$ 2.9$ million from $\mathrm{CNPq}$ and $\mathrm{R} \$ 11$ million from MCTI/FNDCT.

The recent years have seen important actions for PROANTAR. In 2016, new equipment was purchased for Brazilian polar vessels and maintenance activities, reaching the sum of $\mathrm{R} \$$ 4 million. Besides, due to the lack of resource allocation to issue a new call to fund Antarctic 


\section{Discussion}

Paper

Brazil in Antarctica: the scientific and geopolitical importance of PROANTAR in the brazilian strategic surrounding area

studies, a supplementation was added to the 2013 call so that ongoing studies in Antarctica would not stop. Approximately R \$ 2.1 million were directed to this purpose. These sums were divided between the MCTIC (from the ministry's budget and specific resources from CNPq) and amendments from the Parliamentary Front, which destined R \$ 400,000 in 2017 to Antarctic studies. Such amendments have been essential to develop the national Antarctic science. The resources that enabled the issuance of the two calls for PROANTAR-related studies in 2009 and 2013 also counted on the valuable support of these sources.

Graph 2 shows the sums sent to the main actions performed in 2008-2017 regarding Antarctic science in Brazil.

\section{GRAPH 2}

Allocation of resources for Brazilian Antarctic science according to the actions performed (2008-2017)

(In R\$ million)

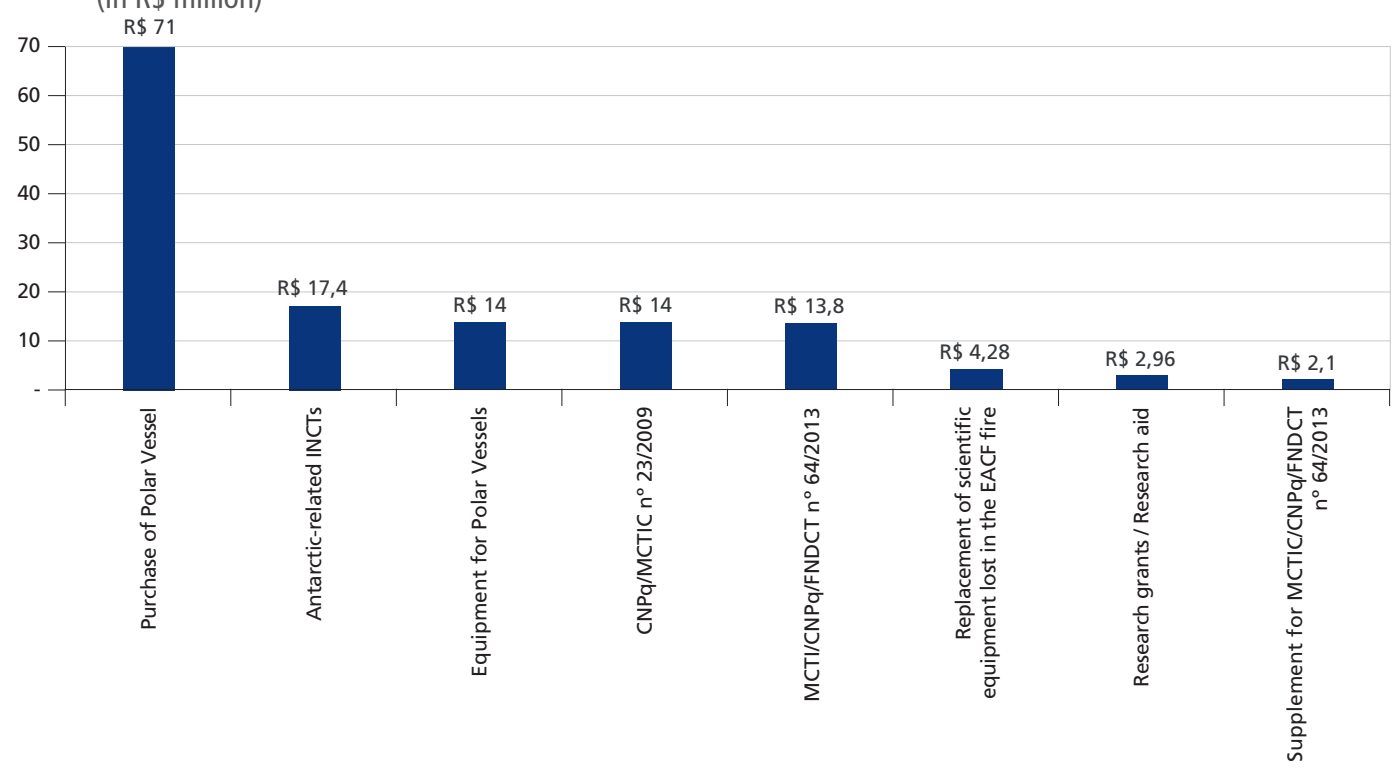

Source: CGOA/MCTIC

Authors' elaboration.

As presented previously, the highest investment to develop the national Antarctic science in the past ten years was the purchase of the polar ship "Almirante Maximiano". This vessel was purchased to assist the oceanographic supporting ship "Ary Rongel” in operations in Antarctica, and it was essential to perform research in several fields of PROANTAR. Besides, the polar ship was also used in Brazilian territorial waters and other regions in the South Atlantic to collect data and improve nautical cartography and oceanographic and meteorological forecasts (Empetur..., 2009). 
The other main resources related to research in Antarctica have been employed with three purposes: to subsidize Antarctic-related INCTs, to fund scientific projects selected by CNPq's calls, and to maintain and purchase equipment for polar ships. We can also mention resources pledged to replace equipment lost in the fire at the Brazilian station. The sum necessary to supplement the funding of projects selected in 2013 must be highlighted in order to underline the importance of issuing calls regularly and therefore to increase the predictability for research activities.

After presenting sums particularly invested in the development of national Antarctic science, we will analyze sums related to the logistical support provided by the Ministry of Defense (via Secretariat of the Inter-ministerial Commission for Sea Resources - SECIRM) to PROANTAR. For that reason, we will present resources available for two actions with the federal budget: Logistical Support to Scientific Research in Antarctica and Rebuilding of Comandante Ferraz Antarctic Station. ${ }^{36}$

GRAPH 3

Expenses paid by SECIRM to provide logistical support to scientific research in Antarctica (2008-2017)

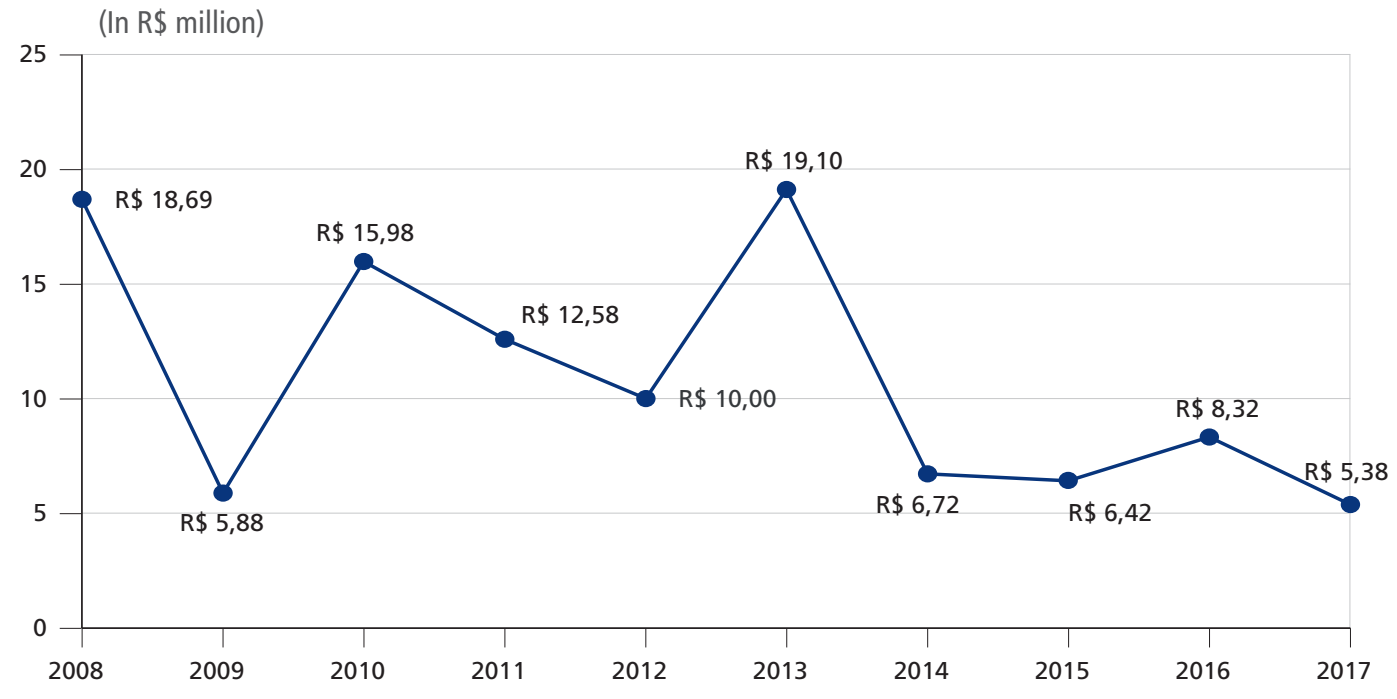

Source: Portal Siga Brasil/Federal Senate. Authors' elaboration.

36. Within the federal budget and the government's budget control tools, the codes of these two actions are 2345 and $14 \mathrm{ML}$, respectively. Both are part of the Oceans, Coast Zone and Antarctica Program, which code in the federal budget system is 2046 . 


\section{Discussion}

Paper

251 Brazil in Antarctica: the scientific and geopolitical importance of PROANTAR in the brazilian strategic surrounding area

Graph 3 indicates a relative variation in the expenses by the Ministry of Defense to provide logistical support to PROANTAR. In 2013, when most of the wreckage was removed from the station after the fire occurred in the previous year and the Emergency Antarctic Modules were purchased, resources reached their maximum value in the ten-year period analyzed. From 2014 forth, we can see lower budgets for logistical aspects. This reduction is mainly due to the need of prioritizing investments to rebuild the EACF, as graph 4 shows.

\section{GRAPH 4}

Expenses paid by SECIRM to rebuild the Comandante Ferraz Antarctic Station (2012-2017) (In R\$ million)

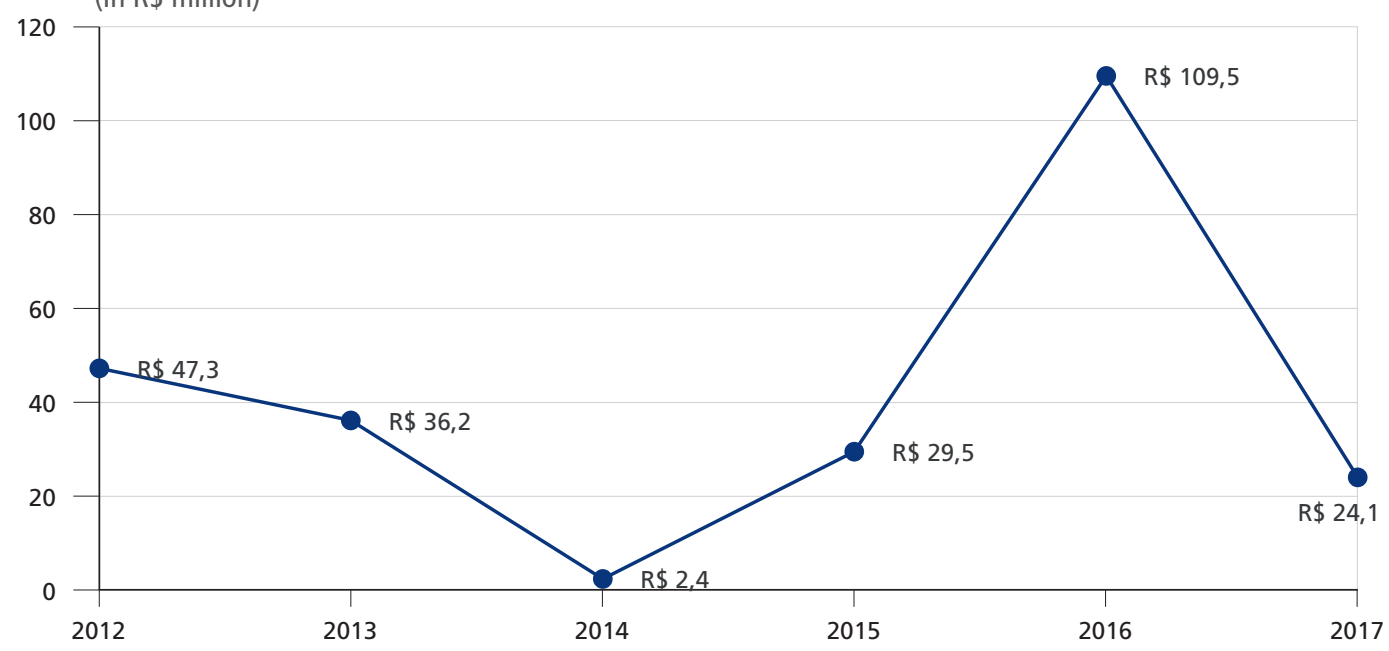

Source: Portal Siga Brasil/Federal Senate. Authors' elaboration.

Resources were redirected to rebuilding the EACF as an emergency just after the accident in 2012. Except for 2014, which registered lower sums invested in Antarctica in all aspects, the minimal annual budget for this purpose was $\mathrm{R} \$ 24.1$ million, in 2017. The maximum value was higher than $\mathrm{R} \$ 100$ million, in 2016. These sums refer to the planning and execution of the disassembling operation of EACF - which demanded, for example, renting a specific ship to remove the wreckage from Antarctica - and also include the design of the new station and the building contract and procedures.

The total payment of the building is estimated to happen only after the delivery of the station, including its commissioning (infrastructure installation), operation manuals, and provisional and definitive receipts regarding the project in order to conclude the contract signed between Brazil and the Chinese construction company Ceiec. 
Although the foundation structures arrived in Antarctica in the first term of 2018, weather conditions did not allow its complete installation this year. Thus, the conclusion of the new EACF is expected to 2019 - consequently, the payment for it will be made only after this date. ${ }^{37}$

In order to examine the total investments by MD in 2008-2017, we drew another graph with the total resources destined to PROANTAR, including logistical aspects and issues related to the rebuilding of the EACF.

GRAPH 5

Total expenses paid by SECIRM within PROANTAR (2008-2017)

(In R\$ million)

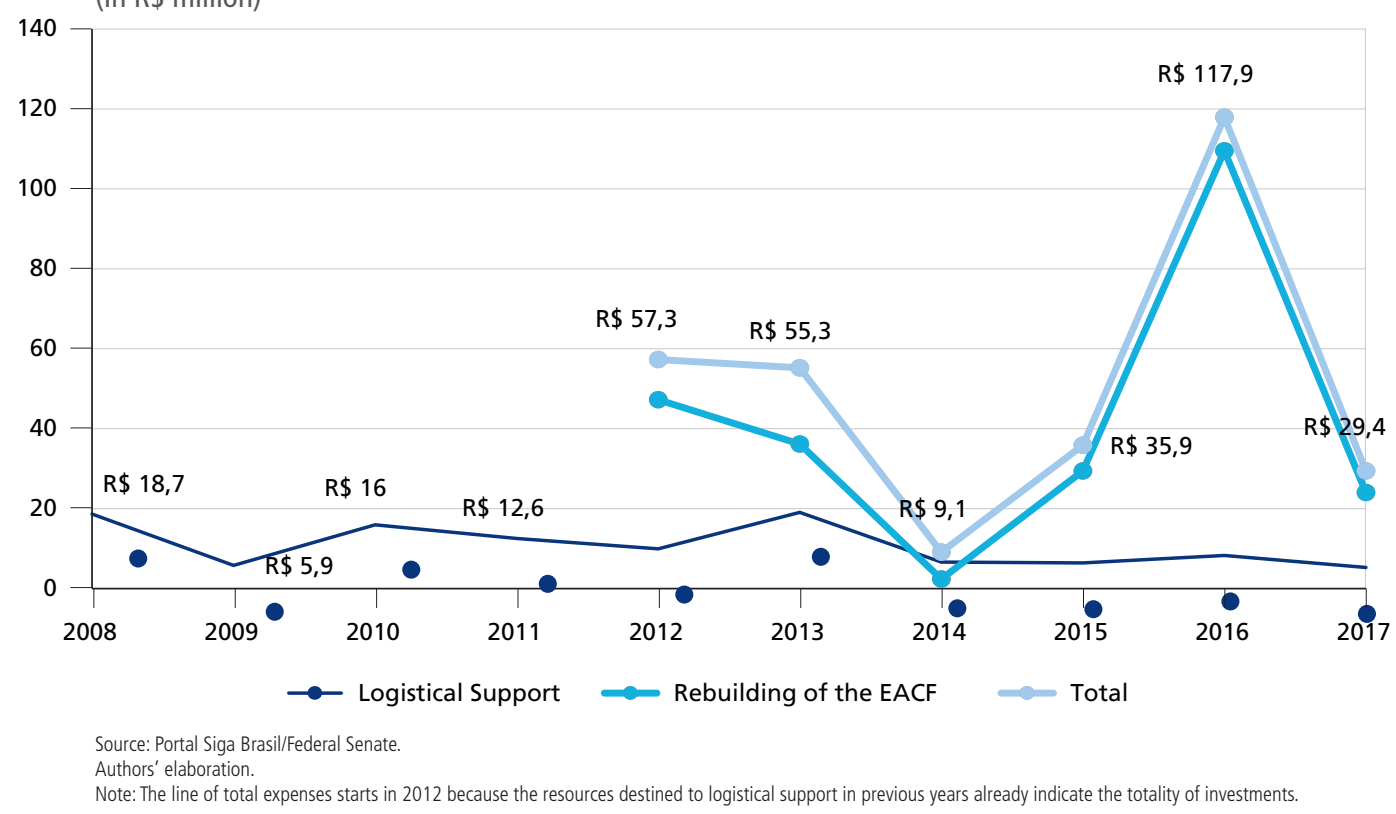

Graph 5 indicates that the need for rebuilding the EACF greatly increased MD's investments in PROANTAR. The average of resources destined to the program between 2008 and 2011 reached R\$ 13.2 million, whereas between 2012 and 2017 it almost quadrupled, achieving $\mathrm{R} \$ 50.8$ million. Considering medium-term and longterm planning, the continuity of this average of investments would be valuable and beneficial for Brazilian interests in Antarctica.

37. The conclusion of the new EACF occurred after the publication of the original version of this text (Texto para Discussão, n. 2423). The inauguration of the station took place in January 2020. 


\section{Discussion}

Paper

251 Brazil in Antarctica: the scientific and geopolitical importance of PROANTAR in the brazilian strategic surrounding area

Regarding PROANTAR's budget, we will also analyze sums from MMA. Responsible for environmental issues in the program, this ministry had a fundamental role in the removal of the wreckage from the EACF in 2012 and in the elaboration of environmentally sustainable aspects of the new station. Besides, in partnership with the Brazilian Navy, this body has developed a risk management of environmental accidents and emergency plans to avoid new disasters. In this regard, the participation of the Brazilian Institute of Environment and Natural Renewable Resources (Ibama), an agency linked to the MMA, has been very important. ${ }^{38}$

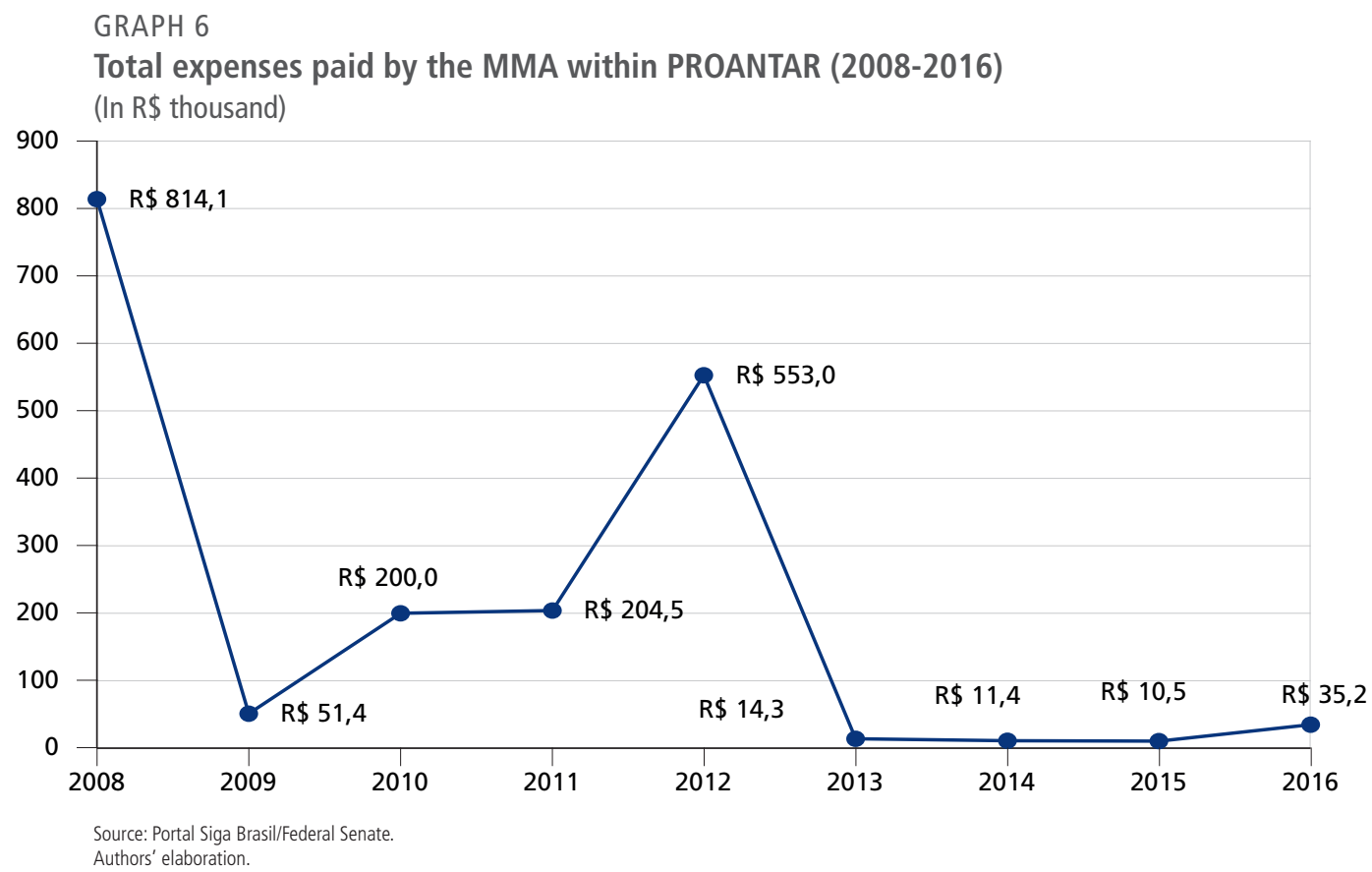

An initial analysis of graph 6 indicates that the sums invested by MMA in PROANTAR are considerably lower than those applied by MCTIC and MD - which can be understood considering the scope of activities developed by each body. However, the resources destined to the MMA's actions in Antarctic sharply dropped after 2013 and remained this way in the next years. The average fell to $\mathrm{R} \$ 17,800$ - compared to R\$364,600 between 2008 and 2012.

38. The MMA has a specific action related to PROANTAR within the federal budget: it was initially called Monitoring of Local and Global Environmental Changes Observed in Antarctica (until 2015), later called Setting Guidelines for Environmental Compliance in Brazilian Activities in Antarctica (in 2016 and 2017). In both periods, the code in the federal budget system is 6618. This action is also part of the Oceans, Coast Zone and Antarctica Program. 
In order to assess budgetary aspects of PROANTAR, this text proposes an integrated analysis of all resources destined to the program in the past years. Graph 7 presents all investments already made by the aforementioned bodies in the following spheres of action: logistical support (MD); rebuilding of the EACF (MD); Antarctic science (MCTIC, CNPq, Capes, FAPERGS, and Parliamentary Front); and environmental aspects (MMA).

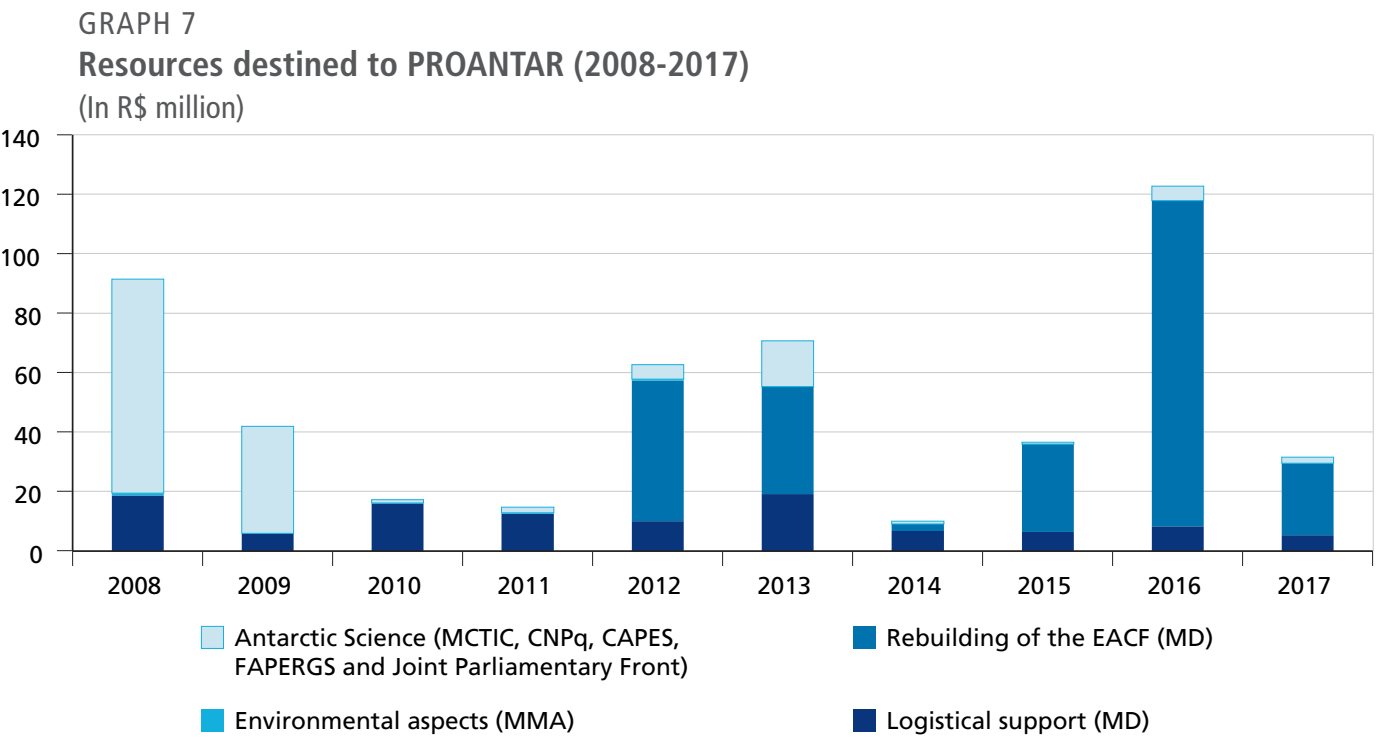

Sources: CGOA/MCTIC; Portal Siga Brasil/Federal Senate. Authors' elaboration.

The data in graph 7 allows important considerations. Firstly, there is some instability in the resource allocation to the program. Therefore, this unpredictability can impair the planning of scientific research conducted in Antarctica and the organization of logistical aspects necessary to develop such activities. Secondly, rebuilding the EACF entailed high costs. Besides the tragic death of two Brazilian Navy officers in the fire in 2012, it affected the development of PROANTAR and, above all, had a great financial impact on the Brazilian Navy's budget, which needed to adjust its priorities to rebuild the station.

Between 2012 and 2017, around R\$ 249 million were invested to rebuild the Brazilian station. As pointed out previously, the initial estimate cost of rebuilding the station was US\$ 99.6 million (approximately R \$ 373.97 million), ${ }^{39}$ which indicates

39. Conversion based on the closing exchange rate of commercial dollar on July $31^{\text {st }}, 2018$ (R\$3.7548).

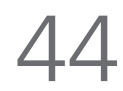


that another R $\$ 100$ million are to be spent for this purpose. For comparison, when adding up all investments made between 2008 and 2017 in PROANTAR (logistical support, Antarctic science, and environmental aspects), the result is $\mathrm{R} \$ 250.6$ million, a sum very close to that of the total value invested in the rebuilding of the station until the end of 2017.

Nevertheless, it is important to point out that this rebuilding will not only allow completely resuming the national Antarctic science development, but will also provide better conditions to execute it. According to the new architectonic design of the station, the built-up area will almost double, which represents a larger number of facilities and the increase in the accommodation capacity. Investing in the rebuilding ultimately means improvement in research and work conditions at the EACF, as well as significant enhancement of the existing infrastructure before the fire. Therefore, destining funds to rebuild the station has been indispensable to the progress of the Brazilian science in Antarctica.

Due to the importance of PROANTAR and to its contributions in scientific aspects and strategic interests, the resources invested in the Brazilian performance in Antarctica must be adequate for scientific development purposes, power projection, and participation in the Antarctic Treaty System. For that reason, public policies and investments in PROANTAR must ensure a predictable budget and therefore an effective planning for the projects and the guarantee for their continuity.

\section{FINAL REMARKS AND RECOMMENDATIONS}

This work presented the scientific, environmental and geopolitical importance of Antarctica, despite the difficulties of accessing this continent and its extreme conditions. It also sought to understand how decisions about this region have reached the current status.

Regarding the Brazilian performance in the Antarctic continent, we have sought to provide an overview of the evolution of the country's interests in Antarctic issues. The Brazilian policy for Antarctica started from a thought concerned with a possible territorial claim and changed to an attitude focused on scientific research and environmental awareness. Thus, the Brazilian Antarctic Program has been internationally recognized, especially for its commitment with the ATS and responsibility with environmental issues. 
After the ratification of the Antarctic Treaty in 1975, Brazil prioritized becoming a consultative party of the instrument and therefore fully participating in the ATS, which was achieved in the 1980s. Signatory of all ATS's conventions and protocols currently in force, Brazil is committed to the rules of this system and stands out for applying them in its policies towards the region.

This study identified that the current Brazilian priority in Antarctica has been to rebuild the Comandante Ferraz Antarctic Station, in order to continue the scientific research activities carried out and expand them. However, it should be noted that, even during the construction, the research continues to be conducted in emergency modules installed for this purpose, as well as on board of Brazilian polar ships and in cooperation projects with other countries, in their vessels and camps, for example.

By presenting the main aspects of Antarctic science developed by Brazil, important advances were identified, such as the systematization made through documents like the "National Strategy for Science, Technology and Innovation" and the action plan "Antarctic Science for Brazil". Considering the great influence of the Antarctic climate over the globe - particularly over South America, due to its proximity -, investments in research in Antarctica should be intensified. Scientific activities in Antarctica also contribute to develop Brazilian science and technology and to ensure the continuity and strengthening of the country's participation in the ATS.

Regarding public policies focused on Antarctic research, it is necessary to stimulate Federal Institutions of Higher Education to carry out selection processes for professors linked to this theme. In addition, it is important to provide research grants dedicated to polar issues and to continue and deepen the integration between PROANTAR and other national scientific programs. Besides, the issuance of calls for research proposals to select and fund scientific projects within PROANTAR should be regular, in order to increase the predictability of the work performed and reduce the risk of its interruption. 


\section{Discussion}

Paper

Brazil in Antarctica: the scientific and geopolitical importance of PROANTAR in the brazilian strategic surrounding area

The analysis of the budgetary issues related to PROANTAR led to significant findings. According to the federal budget of the last years, most sums destined to the program derive from the MD, which is responsible for the logistical support and for rebuilding the EACF; from the MCTIC and CNPq, which are responsible for developing the national Antarctic science; and from the Joint Parliamentary Front in Support of the Brazilian Antarctic Program, whose contributions have been relevant to the program. At a lower extent, the MMA and other bodies such as Capes and FAPERGS have also invested resources in Antarctic activities, with highlight to the performance of Ibama (MMA) in the removal of the fire wreckage in 2012 and in the elaboration of the sustainable aspects of the new station.

Another important aspect observed throughout the analysis is concerned with the instability of funds allocated to the program, which compromises the planning of actions to be developed in the region. Considering that the Brazilian presence in Antarctica is relevant regarding scientific, technological and strategic aspects, Brazil should undertake efforts to ensure that the resources applied for this purpose are sufficient, continuous and guaranteed. The performance in Antarctica affects positively the country's technological and scientific development, also enabling an important participation in the international system within ATS. Therefore, public policies and investments in this performance should be addressed as long-term issues, in order to assure more predictability and certainty to the national Antarctic activities.

For Brazil, the interest in Antarctica must concentrate on the scientific character, with the aim to preserve the continent. The climate in Brazil and in the entire South American continent is greatly influenced by Antarctica, a region that directly interferes in the sea level and in the global climate regulation, which reinforces the importance of its preservation.

It is difficult to point out until when the Antarctic Treaty System and its protection regimes will remain in force, since this issue involves interests from several countries. Brazil, in this regard, must improve awareness campaigns in society about the importance of the Antarctic continent so that the federal budget assigned to PROANTAR's actions can increase. Brazilian presence in Antarctica and the performance of high quality research are essential contributions from Brazil to promote a space exclusively dedicated to science and cooperation among countries in that region. 
PROANTAR clearly features as a program of interest to Brazil, which cannot have its investment flow interrupted. Therefore, it is indicated the strengthening of investments in logistical aspects and scientific development, seeking, in particular, to provide predictability to the resources allocated to research. In addition, the conclusion of the Comandante Ferraz Antarctic Station should be ensured, as well as the maintenance and replacement, whenever necessary, of ships and aircrafts operating directly in the program. It is also recommended to ensure the regular issuance of calls for proposals to select and fund scientific projects, as well as the promotion of education programs for researchers on Antarctic subjects, in order to consolidate long-term goals and scientific objectives aligned with the strategic purposes and ideals of the Brazilian presence in Antarctica.

\section{REFERENCES}

ABDENUR, A. E.; SOUZA NETO, D. M. O Atlântico Sul e a cooperação em defesa entre o Brasil e a África. In: NASSER, R. M.; MORAES, R. F. (Orgs.). O Brasil e a segurança no seu entorno estratégico: América do Sul e Atlântico Sul. Brasília: Ipea, 2014.

A CRIOSFERA. UFRGS, [s.d.]. Available at: <https://goo.gl/J4YfHj>. Access on: 23 jan. 2018.

ANNEX VI to the protocol on environmental protection to the Antarctic treaty: liability arising from environmental emergencies (June 14, 2005). Ecolex, [s.d.]. Available at: <https:// goo.gl/n9LYYm>. Access on: 11 dec. 2017.

ARGENTINA incorpora los Buques Polares “Neftegaz”. Innovaes, 2015. Available at: <https:// goo.gl/fWmq4S>.

ARGENTINA define el ropehielos y el buque polar que abastecerán este verano sus bases antárticas. Télam, 2016. Available at: <https://goo.gl/pK7nSp>.

BENDER, J. Russia and China are drastically scaling up their presence in Antarctica. Business Insider, 2016. Available at: <https://goo.gl/wT8Ecp >.

BOANO, V. Day and night in Antarctica. Ocean Wide, [s.d.]. Available at: <https:// goo.gl/ bYQAsQ>.

BRAZIL. Ministério da Educação. Antártica: ensino fundamental e ensino médio. Brasília: MEC, 2006. v. 9. (Coleção Explorando o Ensino). Available at: <https://goo.gl/eqx5qB >.

Estratégia nacional de defesa. Brasília: Ministério da Defesa, 2012a. Available at: $<$ https://goo.gl/WofMuj>. 
Livro branco de defesa nacional. Brasília: Ministério da Defesa, 2012b. Available at: $<$ https://goo.gl/maikbr>.

Política nacional de defesa: estratégia nacional de defesa. Brasília: Ministério da Defesa, 2012c. Available at: <https://goo.gl/Sx21KH>.

. Ministério da Ciência, Tecnologia, Inovações e Comunicaçôes. Chamada MCTI/ CNPq/FNDCT - Açáo Transversal no 64/2013 - Programa Antártico Brasileiro - PROANTAR. Brasília: Ministério da Ciência, Tecnologia e Inovação, 23 sept. 2013a. Available at: $<$ https://goo.gl/oeHsCK>.

Ciência antártica para o Brasil: um plano de ação para o período 2013-2022. Brasília: MCTIC, 2013b. Available at: <https://goo.gl/TTU3PS>.

Lançada, no Chile, a pedra fundamental da nova Estação Antártica Comandante Ferraz. Ministério da Defesa, 2016. Available at: <https://goo.gl/f7DDNc>.

Estratégia nacional de ciência, tecnologia e inovação 2016-2022. Brasília: MCTIC, 2016b. Available at: <https://goo.gl/Kxj9UN>.

. Pesquisas na estação da Antártica estão paradas, afirma especialista. Câmara Notícias, 2018. Available at: <https://goo.gl/vMWxzc>. Access on: 18 jun. 2018.

Programa Antártico Brasileiro. Comissão Interministerial para Recursos do Mar. Marinha do Brasil. [s.d.]. Available at: <https://goo.gl/Y9wB5J>.

BUEDELER, W. The international geophysical year. Paris: Unesco, 1957. Available at: $<$ https://goo.gl/fEXL4z>.

CIA - CENTRAL INTELLIGENCE AGENCY. The world factbook: Antarctica. Washington: CIA, 2016. Available at: <https://goo.gl/NbS3cc>.

CHIARETTI, D. "Pesquisa antártica brasileira está à beira do colapso", afirma cientista. Valor Econômico, 2017. Available at: <https://goo.gl/gGqfaU>.

COLDEST temperature ever recorded on Earth in Antarctica: -94.7C (-135.8F). The Guardian, 2013. Available at: <https://goo.gl/zJph62>.

COMNAP - COUNCIL OF MANAGERS OF NATIONAL ANTARCTIC PROGRAMS. Antarctic station catalogue. Nova Zelândia: Comnap, 2017. Available at: <https://goo.gl/a4xLfn>

COSTA, J. F. O Brasil e a Antártida. Brasília: Ministério das Relaçōes Exteriores, 11 jun. 1971.

DANTAS, T. Uma experiência no continente gelado. In: ENCONTRO DA FRENTE PARLAMENTAR DO PROGRAMA ANTÁRTICO. Brasília: PROANTAR, jun. 2018.

DAY, D. Antarctica: a biography. Londres: Oxford Press, 2013. 
DESCONTINUIDADE de verbas pode cancelar o PROANTAR em um futuro próximo, alerta cientista. Agência CT\&I, 2015. Available at: <https://goo.gl/UqThkC>. Access on: 18 aug. 2015.

EMPETUR recebe navio polar almirante Maximiano, mais novo navio brasileiro para pesquisa na Antártica. Fator Brasil, 2009. Available at: <https://goo.gl/DgCiyx>.

FEAST, L. Russia thwarts plan for Antarctic ocean sanctuary, China on board. Reuters, 2015. Available at: <https://goo.gl/EczUc1>.

FERREIRA, F. R. G. O sistema do tratado da Antártica: evoluçâo do regime e seu impacto na política externa brasileira. Brasília: Fundação Alexandre de Gusmão, 2009.

FOWLER, M. Antarctic Base McMurdo Station receives sustainable new master plan. ArchDaily. 4 sept. 2017. Available at: <https://goo.gl/ty2KSd>.

GARCÍA, N. Asmar concluirá en octubre el diseño de ingeniería del nuevo rompehielos de la Armada de Chile. Infodefensa.com, 2017a. Available at: <https:/goo.gl/qKc8EJ>.

. Chile inicia construcción del primer rompehielos antártico en Latinoamérica. Infodefensa.com, 2017b. Available at: <https://goo.gl/XyhKYn>.

GAUBET, C. G. As questôes antárticas: algumas perspectivas brasileiras. Revista Sequência, Florianópolis, v. 7, n. 13, jul. 1986. Available at: <https://goo.gl/7DyQ5v>.

HEAVENS, S. Brian Roberts and the origins of the 1959 Antarctic Treaty. Polar Record, v. 52, n. 6, p. 717-729, 2016.

INDIA warms up to BRICS for Antarctica expeditions. The Times of India, 2016. Available at: <https://goo.gl/sGXi7u>.

JACOBSSON, M. Building the international legal framework for Antarctica. In: BERKMAN, P. A. et al. (Eds.). Science diplomacy: science, Antarctica, and the governance of international spaces. Washington: Smithsonian Institution Scholarly Press, 2011. Available at: <https:// goo. $\mathrm{gl} / \mathrm{VhXBCd}>$.

KRASNER, S. International regimes. Ithaca: Cornell University Press, 1983.

LA VOZ. Censo 2010: en la Antártida viven 230 personas, 9 familias y 16 niños. 25 oct. 2010. Available at: <https://goo.gl/7AJ7Tn>.

MARINHA DO BRASIL. Programa Antártico Brasileiro. Comissão Interministerial para Recursos do Mar. [s.d.]. Available at: <https://goo.gl/cHxJxK>. Access on: 12 oct. 2017.

MATTOS, L. F. A inclusão da Antártica no conceito de entorno estratégico brasileiro. Revista da Escola de Guerra Naval, Rio de Janeiro, v. 20, n. 1, p. 165-191, jan./jun. 2014. Available at: <https://goo.gl/6mSEuh>. 
O Brasil e a adesáo ao tratado da Antártica: uma análise de política externa no governo Geisel. 2015. Dissertação (Mestrado) - Universidade Federal Fluminense, Niterói, 2015. Available at: <https://goo.gl/5zPqqN>.

OVERVIEW of SCAR finances. SCAR, [s.d.]. Available at: <https://goo.gl/SPtMdY>.

PARTIES. STA, [s.d.]. Available at: <https://goo.gl/7Km9fs>.

PRB - POLAR RESEARCH BOARD. Antarctic Treaty System: an assessment. Washington: National Academy Press, 1986.

"PROYECTO Antártica I": así será el primer rompehielos construido en Chile. Prensa Antártica, 2017. Available at: <https://goo.gl/yuEYNW>.

REDD, N. T. Antarctica: facts about the coldest continent. Live Science, 2012. Available at: $<$ https://goo.gl/2oKFvQ>.

RODRIGUES, M. S. Resposta brasileira ao grande desafio antártico. In: BRASIL E O SISTEMA DO TRATADO DA ANTÁRTICA. São Paulo: USP, 29 sept. 2016.

ROMERO, G. Countries Rush for Upper Hand in Antarctica. The New York Times, 29 Dec. 2015. Available at: <https://goo.gl/ZJb3xT>.

SECIRM - SECRETARIA DA COMISSÃO INTERMINISTERIAL PARA OS RECURSOS DO MAR. Apresentaçáo. In: ENCONTRO DA FRENTE PARLAMENTAR DO PROGRAMA ANTÁRTICO. Brasília: PROANTAR, 6 jun. 2018.

SIMÕES, J. C. O papel político da ciência antártica. In: SEMINÁRIO ANTÁRTICA 2048. Brasília: ESG; SECIRM; UnB, 16 aug. 2018.

STA - SECRETARIADO DO TRATADO DA ANTÁRTICA. The protocol on environmental protection to the Antarctic Treaty. Buenos Aires: Secretariado do Tratado da Antártica, 1991. Available at: <https://goo.gl/nQhsjT> .

Final report of the thirty-sixth antarctic treaty consultative meeting. Buenos Aires: Secretariat of the Antarctic Treaty, 2013. v. 1. Available at: <https://goo.gl/iDHo89>.

Final report of the fortieth Antarctic treaty consultative meeting. Buenos Aires: STA, 2017. Available at: <https://goo.gl/T4TPED>.

TERRITORIAL claims. Discovering Antarctica, [s.d.]. Available at: <https://goo. gl/6dUshp >. ANTARCTIC TREATY. In: CONFERENCE ON ANTARCTICA, 1959, Washington. Available at: $<$ https://bit.ly/2TGWGNE $>$. 
Ipea - Institute for Applied Economic Research

Press and Communications Office

\section{PUBLISHING DEPARTMENT}

\section{Coordination}

Reginaldo da Silva Domingos

Coordination Assistant

Rafael Augusto Ferreira Cardoso

\section{Supervision}

Camilla de Miranda Mariath Gomes

Everson da Silva Moura

\section{Typesetting}

Aeromilson Trajano de Mesquita

Cristiano Ferreira de Araújo

Danilo Leite de Macedo Tavares

Herllyson da Silva Souza

Jeovah Herculano Szervinsk Junior

Leonardo Hideki Higa

\section{Cover design}

Danielle de Oliveira Ayres

Flaviane Dias de Sant'ana

\section{Graphic design}

Renato Rodrigues Buenos

The manuscripts in languages other than Portuguese published herein have not been proofread.

Ipea Bookstore

SBS - Quadra 1 - Bloco J - Ed. BNDES, Térreo

70076-900 - Brasília - DF - Brazil

Tel.: + 55 (61) 20265336

Email: livraria@ipea.gov.br 

Composed in Adobe Garamond 11/13.2 (text)

Frutiger 47 (headings, graphs and tables)

Brasilia - DF - Brazil 

Ipea's mission

Enhance public policies that are essential to Brazilian development

by producing and disseminating knowledge and by advising

the state in its strategic decisions.

\section{ipea \\ Economic Research}

MINISTRY OF

ECONOMY
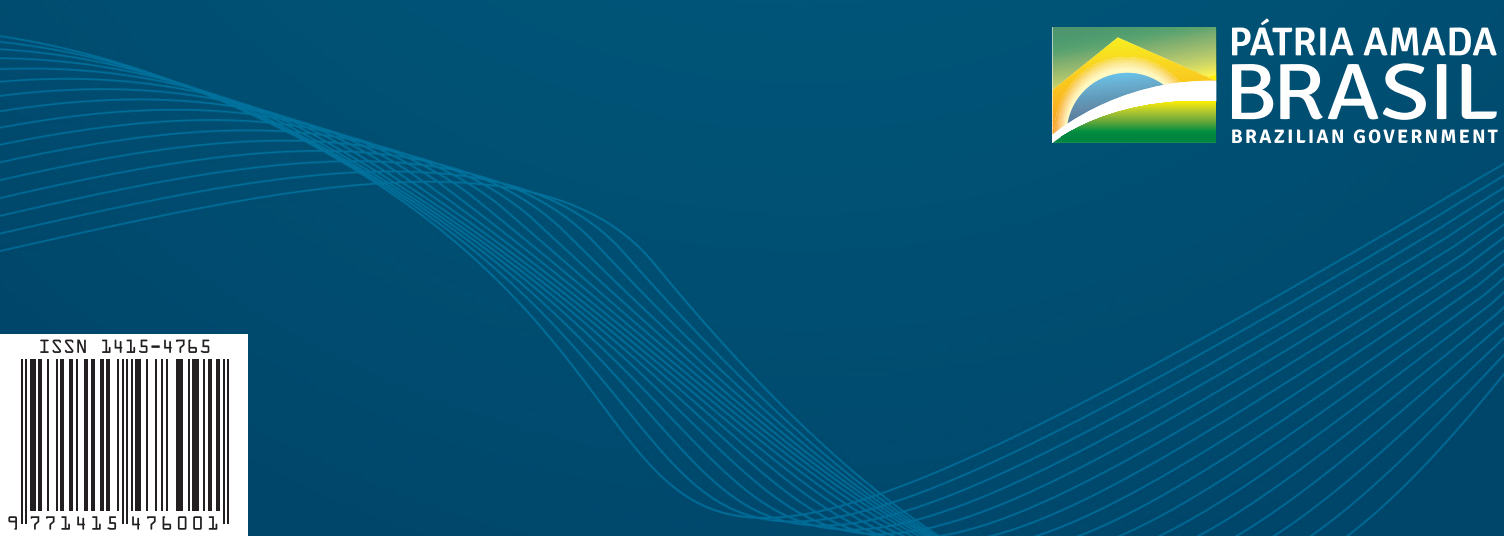